\title{
Multi-secular and regional trends of aquatic biodiversity in European Early Modern paintings: toward an ecological and historical significance
}

\author{
$\underline{\text { Anne-Sophie Tribot }}^{1,2}$, Daniel Faget $^{1}$, Hélö̈se Villesseche $^{2,3}$, Thomas Richard $^{1,2}$ and Thomas Changeux $^{2}$
}

\begin{abstract}
Works of art are testimonies to past civilizations and biodiversity, and provide fundamental information for guiding current conservation programs. The success of such programs requires an understanding of the reference state of ecosystems, which is rarely known because current references are in perpetual slippage toward the acceptance of degraded states. For this reason, international organizations are regularly alerted to the fact that fish and aquatic resources are threatened, signaling a major challenge for our societies. In this article we aim to enrich the historical and ecological knowledge of aquatic resources in Western Europe (Atlantic, North Sea, and Mediterranean Sea) by analyzing the taxonomic composition of aquatic biodiversity as represented in Early Modern paintings, using the statistical tools of numerical ecology. The geographic and temporal variations of the biodiversity represented in these paintings are interpreted according to environmental and human pressures, which we differentiate between using technical and socio-cultural "sieves." Our results highlight the natural and anthropic factors that shape the spatial and temporal variations of the aquatic species depicted. These species belong to significantly different periods and regions, with a convergence between the origin of the paintings and the biogeographic area of the species. We show an overall decrease over time of represented taxa, and particularly of continental and freshwater species. We discuss the results in the light of previous works of historical ecology, archeology, history, and biology. Finally, we discuss the relevance and potential future contributions of the method developed herein to better understand the past reference state of aquatic socio-ecosystems.
\end{abstract}

Key Words: art; biodiversity; freshwater; historical ecology; marine; painting

\section{INTRODUCTION}

Biodiversity has been depicted in art by humans for the past 35,000 years, thus constituting a major source of inspiration for mankind. Art works and historical legacy are testimonies of past biodiversity and civilizations, and provide crucial information for the orientation of current conservation and restoration programs. Indeed, the implementation of such programs requires sufficient knowledge of the reference state, or baseline, of an ecosystem. When this baseline needs to be more accurately informed, art works from the past, reviewed from a historical point of view, can provide valuable clues (Guidetti and Micheli 2011). This is especially true for aquatic socio-ecosystems that are particularly affected by the biodiversity crisis (Worm et al. 2006), and in which the preservation of resources represents a major human and societal issue (Liquete et al. 2013, Schwerdtner Máñez et al. 2014). Indeed, previous studies have shown strong evidence of the existence of shifting baseline syndrome specific to exploited marine ecosystems (Papworth et al. 2009), meaning a generational amnesia leading to the loss of the reference state (Pauly 1995). Further to this, Jackson et al. (2001) used an innovative method involving paleoecological, archaeological, and historical data to study the long-term impact of overfishing on ecological communities. Numerous marine biologists have since engaged in historical approaches applied to exploited marine ecosystems (e.g., Schwerdtner Máñez et al. 2014), usually using trophic models to validate and interpret past variations of marine biodiversity (e.g., Lotze et al. 2011). More recently, a few freshwater ecosystems have been studied to permit the reconstruction of long-term historical changes of exploited fish populations in rivers (e.g., Lenders 2017, Haidvogl 2018) and lakes (e.g., Schmidt et al. 2011). In his review of historical ecology, Szabó (2015) classified this field as a mainly ecosystemcentered approach (in contrast to human-centered approaches), aware that the overall research trend combines ecology and anthropology. The present article clearly belongs to these last categories because it treats a typical human production: art.

We propose in this article to investigate artistic representations of aquatic biodiversity using a transdisciplinary approach corresponding to the main author's specialties: ecology and history. As undertaken by Begossi and Caires (2015), we will use the occurrence of artistic representations of aquatic species as temporal and geographical indicators to better inform the past composition of these species and their abundances.

\section{Aquatic biodiversity in art: an overview in Europe}

Aquatic biodiversity in art is an infrequent but constant motif. In their introduction to 80 examples of fish imagery in art, Moyle and Moyle (1991) summarized the depiction of fishes in this way, and their notion was corroborated by the similar approach that Charmantier (2014) applied to crustaceans. The European cave art bestiary dating from prehistoric times consists essentially of large mammals. Depictions of aquatic biodiversity are rare, and even the fishes are difficult to identify (Cleyet-Merle 1990), with the notable exception of the salmon figuring in "l'Abri du poisson" (Eyzies de Tayac), which dates back 25,000 years and shows the typical morphology of a spawning specimen. Only a few aquatic species can be dated back to the Bronze and Iron Age Scandinavian civilizations, and they are poorly recognizable (e.g., the fish of the Kivik royal grave, Sweden, 600 years BCE). With a history of earlier artistic traditions, many Mediterranean civilizations represented aquatic biodiversity in a more realistic way: the open sea fauna of the Minoans (Crete, between 2700 and

${ }^{1}$ UMR TELEMMe, MMSH, Aix-Marseille University, CNRS, Aix-en-Provence, France, ${ }^{2}$ Aix Marseille Univ, Université de Toulon, CNRS, IRD, MIO, Marseille, France, ${ }^{3}$ Current affiliation: DigitAg, INRAE, MUSE, Montpellier SupAgro, Montpellier, France 
1200 BCE), coastal fishes, crustaceans and mollusks in Greek, Sicilian, Campanian, Paestan, and Apulien pottery (between 800 and 100 BCE, see Delorme [1987], McPhee and Trendall [1987] and Metzger [1990] for more details), the representations of live aquatic organisms in Roman mosaics (from 500 to 100 BCE, as reported by Guidetti and Micheli in 2011), or the still lifes featuring sea food in Xenia style mosaics. Later, during the Middle Ages, fish took on Christian symbolism, and the realism of their representation was no longer of concern. It was not until the Renaissance that the depiction of aquatic biodiversity became recognizable again. The Early Modern period in Europe started with the Renaissance and ended with the Industrial Revolution, spanning approximately the years 1500 to 1800 . These three centuries saw an increase of artistic productions in all fields, with painting persisting as the major medium in figurative art until the invention of photography (Gombrich et al. 1997).

\section{Purposes of the present study}

The objective of the present study is to analyze the taxonomic composition of aquatic biodiversity represented in European Early Modern paintings, using the statistical tools of numerical ecology. First, we undertake a set of explanatory analyses to identify the main variations in the pictorial representation of aquatic biodiversity across space and time. Second, statistical tests and representations are used to analyze these variations more precisely, according to the biological and biogeographical characteristics of the species. Finally, we endeavor to interpret these variations in the light of historical hypotheses related to technical and socio-cultural factors that may influence the representation of species in painting. To address ecological significance, we took into account ecosystem variations in relation with the biogeography of the species and trends in population changes.

Surprisingly, such a transdisciplinary study has never been done before. A search in the Web of Science revealed only one similar study on paintings (Goddeeris et al. 2002), which concerned a single artist, Frans Snyders, and which was limited to the depiction of birds seen from a single socio-cultural angle, that of gastronomy. To our knowledge, there are only two publications that carry out statistical analyses of the frequency of fish images: the first explores archival photographs of fishing competitions (McClenachan 2009), and the second examines naturalistic drawings that do not pre-date the 19th century (Fortibuoni et al. 2010)

Before a given species can be represented in a painting, many different conditions must align. Large-scale spatial and temporal variations in the depiction of aquatic biodiversity may reflect changes in climate, overexploitation, and habitat modification (Fig. 1). For this reason, we have applied two main "sieves" to sort the representations of aquatic taxa in paintings. First, a technical sieve that determines the availability of the specimen: Has it been caught with a specific fishing technique, or raised by aquaculture before being transported to the place where the artist worked? This knowledge is often made possible thanks to the depiction of special conservation techniques in the paintings. Second, a socio-cultural sieve that sorts primarily according to food preferences, interrelated with fishing, aquaculture, and conservation techniques. The aesthetic choices of the artist are also related to this last category.
Fig. 1. Main selection sieves of species represented in paintings. Painting: Snyders, Frans. Fish Market. Flanders, between 1618 and 1621. Oil on canvas. Image is used from https://www. hermitagemuseum.org, courtesy of The State Hermitage Museum, St. Petersburg, Russia.
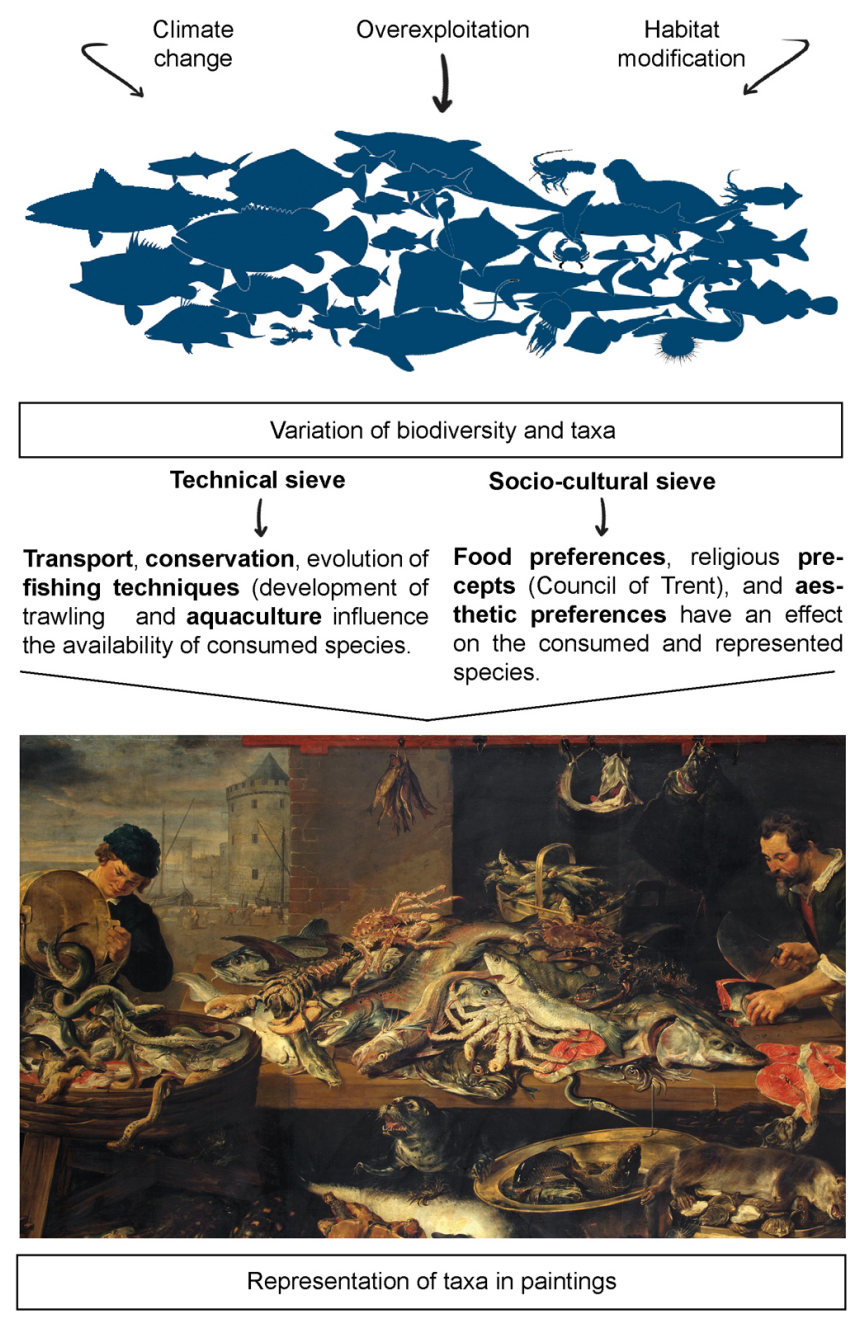

Our approach involves four steps: the collection of a sufficient number of paintings to enable statistical analysis, the identification of species or taxa, the study of their spatial and temporal variations, and finally, the interpretation of these variations through the identification of ecosystem variations (under natural and human pressures) and socio-cultural (or historical) sieves that are involved in the selection of the depicted species. These interpretations are described in the Discussion because they are based primarily on historical assumptions rather than on the statistical analyses performed in this study.

This study of paintings representing aquatic biodiversity over three centuries and across the different regions of Europe provides the opportunity to better understand the variation of the taxonomic composition of the different periods and regions through socio-cultural and technical sieves. These elements will 
constitute relevant keys for an improved understanding of the evolution of aquatic socio-ecosystems during the Early Modern period.

\section{METHODS}

\section{Studied regions}

The European peninsula is bounded to the north and west by the Atlantic Ocean and to the south by the Mediterranean Sea. Following Longhurst (2007), this region comprises two distinct provinces: the Northeast Atlantic Continental Shelf (NECS) and the Mediterranean Sea (MEDI), which are physically separated by the Straits of Gibraltar. Abundant oceanic precipitations feed numerous inland rivers and lakes of the Atlantic coast, to the contrary of the dry climate surrounding the Mediterranean Sea. This contrasted climate and the common geological history of the Mediterranean region explain the existence of many aquatic marine or continental endemic species (Tortonese 1985, Bianchi and Morri 2000, Boudouresque 2004, Coll et al. 2010, Tierno de Figueroa et al. 2013). The Atlantic region hosts more widely distributed species, some of which have been very important for human consumption since prehistoric times, but that are not adapted to the Mediterranean environment, e.g., Atlantic salmon (Salmo salar Linnaeus 1758), Atlantic herring (Clupea harengus Linnaeus 1758), and Atlantic cod (Gadus morhua Linnaeus 1758).

\section{Period}

The Early Modern period in Europe, spanning the years 1500 to 1800 , is included within the longer climatic cooling period known as the Little Ice Age that began at the beginning of the 14th century and ended at the end of the 19th century (Lamb 1967, Le Roy Ladurie 1993). The effects of this climate change as represented in art, and especially in painting, have been well documented by several authors (Neuberger 1970, Burroughs 1981, Neuberger and Thornes 2005).

During this 300-year period, the European population doubled (De Vries 1994). This trend was particularly significant in Northern Europe, in countries such as Ireland, Belgium, or England, which are all important fishing countries. Central European countries experienced an average progression. On the contrary, Southern countries increased in population by only twothirds for many reasons, including the Thirty Years War during the first half of the 17th century, several outbreaks of plague, the emigration of Protestants to the North, and the shift of the main trade routes from the Mediterranean to the Atlantic.

This period is characterized by the intensification of exchanges both within Europe and between Europe and the rest of the world, made possible by the discovery of remote ecosystems and by the development of distant fisheries that were able to return their catches to Europe thanks to very well-controlled conservation processes, e.g., salting and smoking. As a luxury commodity, the trade in fresh seafood acquired structure at the national level with the establishment of special wholesale fishmonger routes. For instance, the "Chasse-marées" vessels were able to supply Paris with fresh seafood, $100 \mathrm{~km}$ from the sea (Fontaine-Bayer 1993, Robert 2018). New fishing techniques, such as benthic trawling or pair trawling, became more widespread. Inland fish farming, mostly practiced by monks, was essential for food during the 40 days of Christian Lent before Easter, when no other meat or animal products were eaten. This food ban was renewed at the beginning of this period with the Council of Trent (1545-1563). All these factors provided many opportunities for painters seeking inspiration from subjects of aquatic biodiversity.

Just as portrait artists painted from living subjects, the Renaissance witnessed the advent of still life painting in connection with "Vanitas," symbolizing the ephemeral nature of life and associated with the Protestant religious reforms, the practice of Christian Lent, and the consumption of fish. From the 16 th to the 17 th centuries, art, science, and techniques progressed simultaneously, carried forward by the same people. In the 18th century, the Age of Enlightenment led to the exploration of scientific approaches, which would finally lead to the separation of art and science, a rupture that goes beyond the scope of our study. At roughly the same time, new artistic movements broke away from realism, leading finally to Impressionism in the 19th century and the production of artworks where the depiction of species as such remained non-recognizable "impressions."

\section{Data sources}

Most of the paintings we examined were obtained by searching the web using museum databases or grouped museums databases such as "Joconde" in France (Ministère de la Culture, France, http://www2.culture.gouv.fr/documentation/joconde/fr/pres.htm). The objective was to have the most reliable information on the artist behind each painting, the location, and the period of the work. The paintings $(\mathrm{n}=73)$ were selected for their realism, and a sufficiently good quality image had to be available to enable species identification. Some museums were questioned directly to ensure the traceability of the painting and to obtain quality reproductions and copyrights.

\section{Data treatment}

Species selection, identification, and characterization

The depicted species were identified by a panel of more than 10 specialists from three different institutions (see Acknowledgements). A protocol was determined by the panel in order to adopt the level of precision they deemed necessary. For each painting, every specimen or group of specimens of the same species was identified using a figure that corresponded to one line in a data frame that was filled in by each specialist to indicate presence (1)/absence (0). Finally, many of the presumed "species" identified were not determined at the species level and are identified in the text as taxon/taxa. They were all described using the appropriate taxonomic level following TAXREF nomenclature. Any representations of shells without their living organism inside, and any obviously mounted fishes such as pufferfish (Tetraodontidae), were excluded from identification because of their obvious provenance from worldwide collections (e.g., "Cabinet of Curiosities") rather than belonging to the local available aquatic biodiversity. The few algae were also excluded they are not portrayed with the same fidelity as the fauna. The size of specimens was not retained because their relative lengths are not necessarily respected in the paintings.

Every taxon was characterized by its biogeographical status and habitat group using the Ocean Biodiversity Information System (OBIS) database and the French Freshwater fish guide (Keith et al. 2020) with the following nomenclature: Biogeographical Status (European; Atlantic and North Sea; Mediterranean; Introduced); 
and Habitat Group (Continental; Migratory and Pelagic Amphihaline; Sea; Sea-Benthic; Sea-Demersal; Sea-Pelagic). When these data were available, trophic level, maximum size, weight, and lifespan were determined for fishes using FishBase (https://www.fishbase.org). Fishing gear was identified following the authors' expertise for the period.

\section{Positioning of paintings in space and time}

We assigned each painting to a period and a region according to the artists' attribution currently in use by the museum. The life of each artist ( $n=41$ ) was documented using Bénézit (2006) and the website of the Netherlands Institute for Art History (https://rkd. n1/en/explore/artists). The date and places of birth and death were the most consistently known elements of information, alongside the major town of activity. This distribution was determined in order to have a sufficient number of paintings for a statistical analysis of spatial and temporal variations.

\section{General distribution of the taxa across the paintings}

For regions and periods alike, we analyzed the distribution of taxa in two steps: (i) first, main distribution trends were highlighted using multivariate analyses and then, (ii) the relationship between these trends and the biological and biogeographical characteristics of the species were analyzed using statistical tests and comparisons of proportions. In order to highlight the distribution of taxa across the paintings, we used the non-normalized principal component analysis (PCA) available in FactoMineR (Lê et al. 2008). PCA is a dimensionalityreduction method that aims to determine the principal components of a data set, based on the variance of combined variables. We used this method herein to visualize how well the principal components fit the variables of interest (region and period), and thus to identify a pattern in the representation of taxa across space and time. Non-normalized PCA was chosen in order to keep the respective variances of each variable (data are centered but not standardized). In order to test the relationship between regions of representation and the distribution of taxa according to their characteristics (Biogeographical Status, Habitat Group, Trophic Level, and Fishing Gear), we performed Pearson's chi-squared tests based on the counts of each taxon across regions. To quantify more precisely the distribution of each taxon, we compared the proportion of their presence in the paintings of each region (in \%) and calculated the difference of proportion between the two regions. Thus, if the obtained value is positive, the taxon appears mainly in the Atlantic-North Sea region, whereas a negative value indicates that the taxon is mainly represented in Mediterranean paintings. We used this method to quantify each taxon according to Biogeographical Status, Habitat Group, Trophic Level, and Fishing Gear.

To analyze the relationship between the distribution of taxa and the three periods (16th, 17th, and 18th centuries), we performed the same set of chi-squared tests. We then plotted the residuals of each variable for significant chi-squared tests. To analyze the variations of the representation of each taxon individually during the three periods, we then calculated the standard deviation of the count of each taxon within the three periods.

Focus on selected taxa

In order to identify the most representative species of the geographical and temporal distribution of the different taxa, we selected the taxa that exhibited the most variance in the previous
PCA (at least $80 \%$ of the explained variance). We then performed a second non-normalized PCA using the selected taxa.

\section{RESULTS}

\section{Identified species and taxa}

Among the 73 selected paintings (Appendix 1), 126 taxa were identified, including 67 families among 34 different orders (Appendix 2). The most represented classes were Actinopterygii (i.e., ray-finned fishes, 69\%) and Malacostraca (i.e., crustaceans, $10 \%$ ). These taxa are all commercial, and are fished for food. Other represented classes were Mammalia (i.e., mammals, 5.5\%), Bivalvia (i.e., mollusks with two shells, $4.5 \%$ ), Elasmobranchii (i.e., sharks and rays, 3.5\%), Cephalopoda (i.e., squids, octopus, and cuttlefish, 2.5\%), Reptilia (turtles $2 \%$ ), Gastropoda (i.e., snails, $1.5 \%$ ), Petromyzontidae (i.e., lampreys, $1.5 \%$ ), and Echinoidae (i.e., sea urchins, $<1 \%$ ). Represented taxa were from both marine environments $(80 \%)$ and freshwater environments $(20 \%)$. Note the absence of whales from the corpus. We also identified an introduced taxon: Cyprinus carpio, Linnaeus 1758 (i.e., common carp).

\section{General distribution of paintings in space and time}

The 73 paintings have been attributed to 41 artists who were active in two regions, the Atlantic Ocean-North Sea and the Mediterranean Sea (Fig. 2a) during three periods (the 16th, 17th, and 18th centuries (Fig. 2b). Further to the distribution of the artists by city within the two regions, we identified two schools of art: the Flemish School (related to the Atlantic and North Sea) and the Italian School (related to the Mediterranean). We partitioned the 73 paintings as follows (Table 1): those representing Atlantic-North Sea species $(n=44)$, and those depicting Mediterranean species $(n=29)$. They date from the 16 th $(\mathrm{n}=23)$, the 17 th $(\mathrm{n}=28)$, and the 18 th $(\mathrm{n}=22)$ centuries. Note that the dataset is rather unbalanced regarding the geographic origin of the paintings. However, the Pearson's chisquared test based on the count of each taxon across the three periods was not significant for Biogeographical Status ( $p$-value $=0.643$ ), showing that the imbalance in the paintings dataset did not affect the distribution of taxa across the three time periods.

Table 1. Number of paintings by period and region.

\begin{tabular}{lcccc}
\hline \hline & $\begin{array}{c}16 \text { th } \\
\text { Century }\end{array}$ & $\begin{array}{c}17 \text { th } \\
\text { Century }\end{array}$ & $\begin{array}{c}18 \text { th } \\
\text { Century }\end{array}$ & Total \\
\hline Atlantic-North & 15 & 19 & 10 & 44 \\
Sea & 8 & 9 & 12 & 29 \\
Mediterranean & 23 & 28 & 22 & 73 \\
Total & & & & \\
\hline
\end{tabular}

\section{General distribution of the taxa across the paintings}

Distribution of the taxa across regions

The distribution of taxa in the Atlantic-North Sea and Mediterranean paintings was seen to depend on the biogeographical origin and the natural habitat of the taxa. Indeed, Pearson's chi-squared test (based on the count of each taxon across regions according to Biogeographical Status and Habitat Group) showed a significant relationship (respectively, p-value $=9.971 \times 10-16$ and $1.464 \times 10-08)$, while tests based on 
Fig. 2. Locations and dates of birth and death of the artists included in the study. (a) Location of the cities of birth and death, and of the main activity of the artists included in the study with delineation of their zonal belonging. (b) Dates of birth and death of the artists, colored according to their region of origin.

\section{a)}

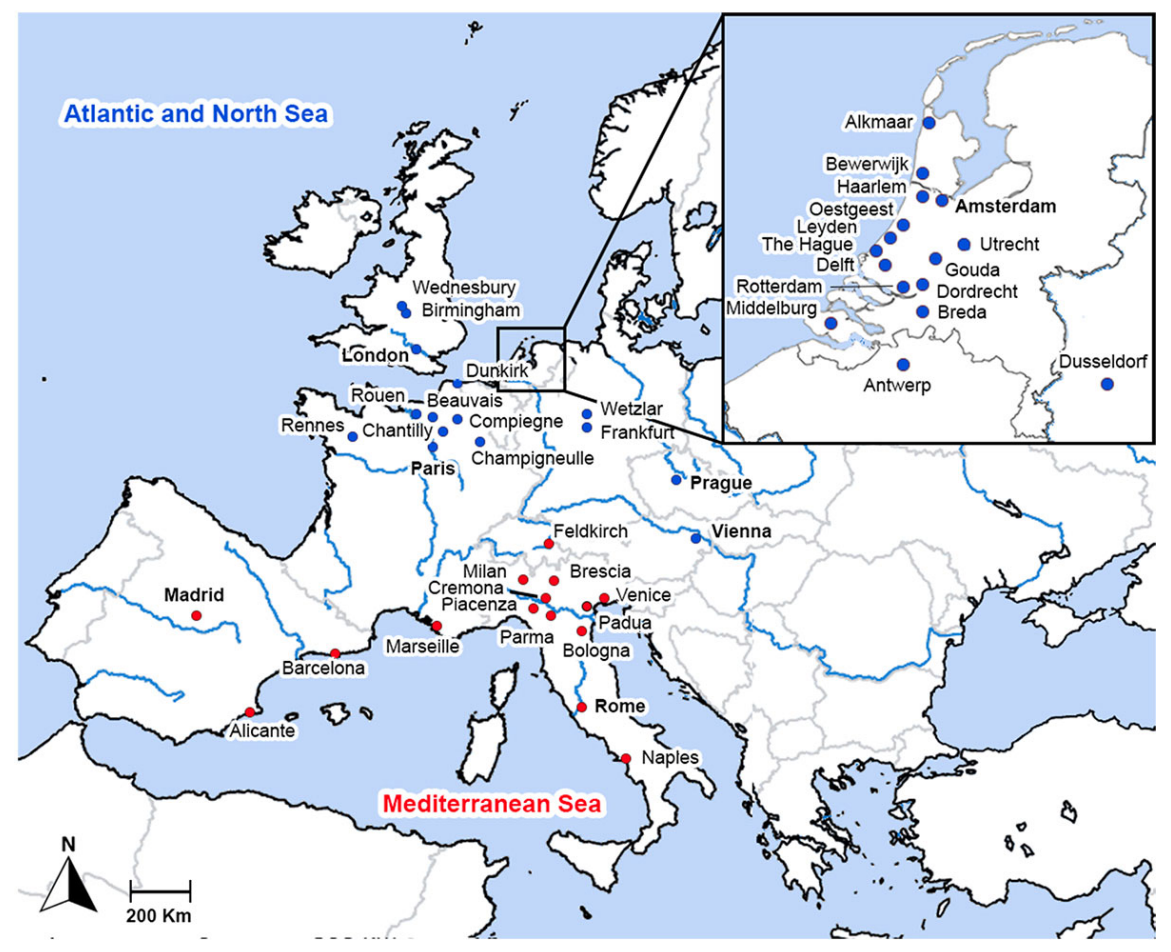

b)

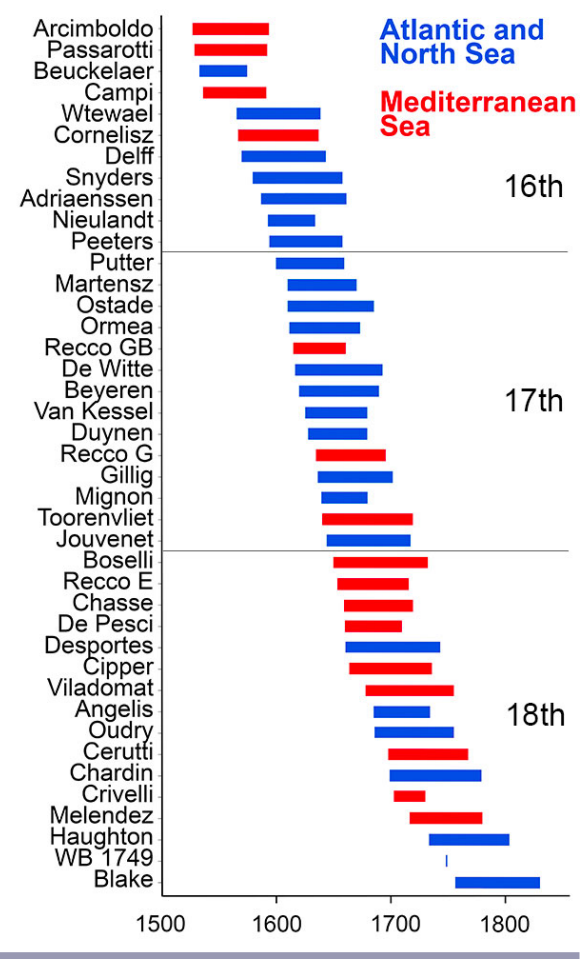

Trophic Level and Fishing Gear were not significant $(\mathrm{p}$-values $=$ 0.021 and 0.285 , respectively).

Generally speaking, the region in which a taxon was represented was consistent with the geographical origin of the painting, showing that painters tended to represent the taxa they could observe locally. Regarding the habitat, Mediterranean paintings showed more pelagic taxa, suggesting that these species were probably more targeted by the Mediterranean fisheries. To visualize more precisely the distribution of each taxon according to its Biogeographical Status and Habitat Group across regions, we plotted the proportion of taxa (in \%) in the given region for each painting (see Fig. 3b).

\section{Distribution of the taxa across periods}

The abundance (in \%) of each class of taxa according to the three periods is shown in Fig. 4a. All classes except Malacostraca and Bivalvia showed a decrease between the 17th and 18th centuries. Reptilia, Petromyzontidae, and Mammalia (harbor porpoises, Eurasian otters, seals and dolphins) were depicted in the 16th and/ or 17 th centuries, but disappear (except Delphinidae) from the 18th century paintings. Conversely, Gastropoda (snails) and Echinoidea (sea urchins) are present only from the 18th century. The abundance (in \%) of each taxon in the three periods is plotted in Fig. 4b. To identify the taxa with the highest shifts during the periods, we performed the standard deviations of abundance across the three periods, and selected the first decile of this distribution $(\mathrm{n}=13$ taxa).
The Pearson's chi-squared tests based on the count of each taxon across the three periods showed a significant relationship with Habitat Group $(\mathrm{p}$-value $=0.002)$ and Trophic Level $(\mathrm{p}$-value $=$ $\left.9.427 .10^{-7}\right)$, but not for Biogeographical Status $(p$-value $=0.643)$ and Fishing Gear (p-value $=0.046$ ). Values of the residuals for chi-squared tests of Habitat Group and Trophic Level are shown in Fig.4c.

\section{Focus on selected taxa}

Identified groups

In order to identify the most representative species of the geographical and temporal distribution of the different taxa, we performed a first PCA using all the taxa of the dataset (explained variance: Axis $1=10.82 \%$, Axis $2=7.90 \%$ ). We then selected the 20 taxa with the highest explained variance of the previous PCA ( $80 \%$ of the explained variance) and performed a second nonnormalized PCA by using these 20 selected taxa (explained variance: Axis $1=20.09 \%$, Axis $2=15.98 \%$, Fig. 5a). Axis 1 was mainly explained by taxa represented in (i) Mediterranean paintings from the 18th century, and (ii) Atlantic-North Sea paintings from the 16th and 17 th centuries ( $99 \%$ of the explained variance). This suggests that the abundance of Atlantic-North Sea taxa decreased from the $17 \mathrm{th}$. Axis 2 was mainly explained by freshwater taxa (74\% of the explained variance). The PCA was thus composed of three groups: one of freshwater taxa, with the exception of C. harengus (Group 1), a second group of taxa mainly represented in Atlantic-North Sea paintings from the 16th and 
Fig. 3. Representation in paintings of taxa by region. Differences between the proportions (in \%) of paintings (located in the Mediterranean Sea and in the Atlantic-North Sea) where each selected taxon is represented. Left panel: taxa colored according to Biogeography. Right panel: taxa colored according to Habitat Group. Only the taxa with a difference of more than 5\% between the Atlantic-North Sea and the Mediterranean Sea are shown.

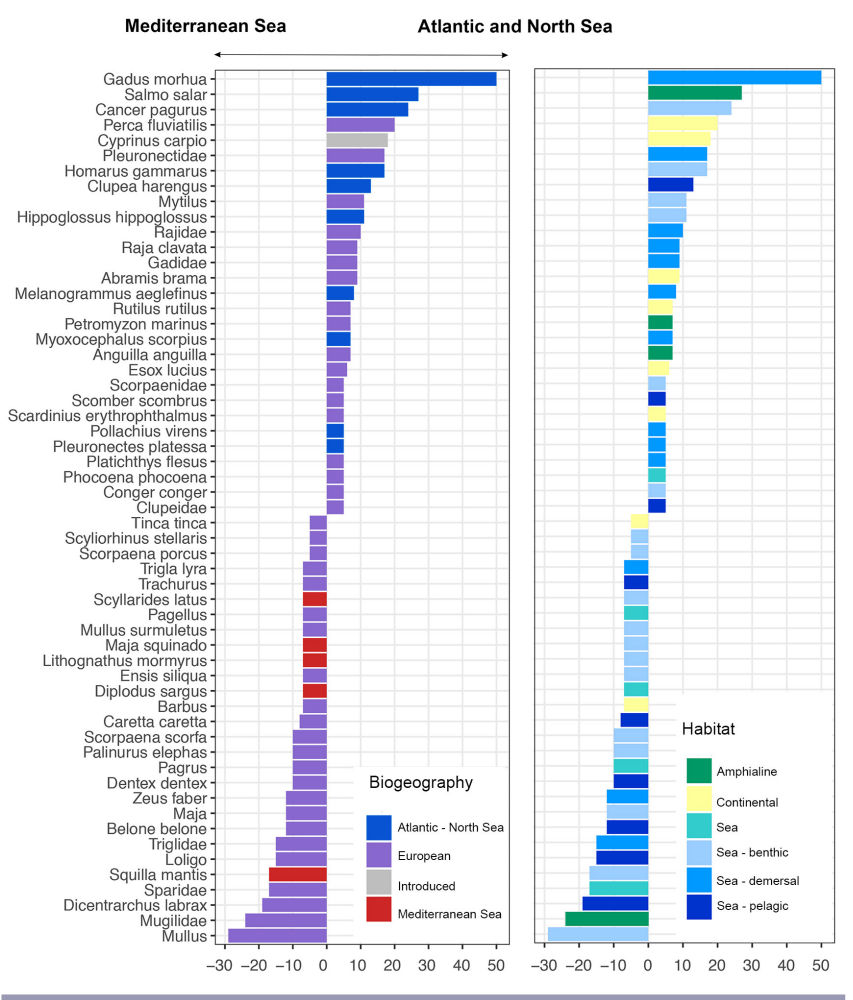

17 th centuries (Group 2), and a third group composed of taxa mainly represented in 18 th century Mediterranean paintings (Group 3). To test if the distribution of selected taxa was dependent on region and period, we performed a Pearson's chisquared test based on a presence/absence matrix of each taxon in each painting, according to the three periods and the two regions. For both the periods and the regions, the tests were significant ( $\mathrm{p}$ values $=0.013$ and $1.395 .10^{-7}$, respectively), showing that distributions of the taxa were statistically dependent across periods and regions

\section{Main paintings}

The paintings belonged to three periods and two regions (as shown by the PCAs in Fig.5b and Fig.5c). Note that the Mediterranean paintings tend to date from the 18th century, whereas the Atlantic paintings correspond in general to the 16th and 17 th centuries. Regarding the distribution of the paintings, those that contributed the most to the variance of the distribution were P15 (Frans Snyders, Fish Stall, 1618-1621), P14 (Frans Snyders, The Fishmongers, 16th c.), and P45 (Jacob Van Nieulandt, Fishmongers, 17th c.) for axis 1 (23.02\% of explained variance), and P3 (Joachim Beuckelear, The Fishmongers, 16th c.), P2 (Joachim Beuckelear, The Fishmongers, 16th c.), and P47

Fig. 4. Representation in paintings of taxa by period. (a) Relative abundance (in \%) of class of taxa in the paintings according to the three periods: $16 \mathrm{th}, 17 \mathrm{th}$, and 18th centuries. (b) Abundance (in \%) of taxa in the paintings according to the three periods: $16 \mathrm{th}, 17 \mathrm{th}$, and $18 \mathrm{th}$ centuries. Only the species with the highest variations are shown (based on the first decile of the distribution of standard deviation between the three periods). (c) Residual values of chi squared tests performed according to Habitat Group ( $\mathrm{p}$-value $=0.002$ ) and Trophic Level $(\mathrm{p}$-value $=9.427 \times 10-7)$. Only the residuals of significant tests are shown.

a)

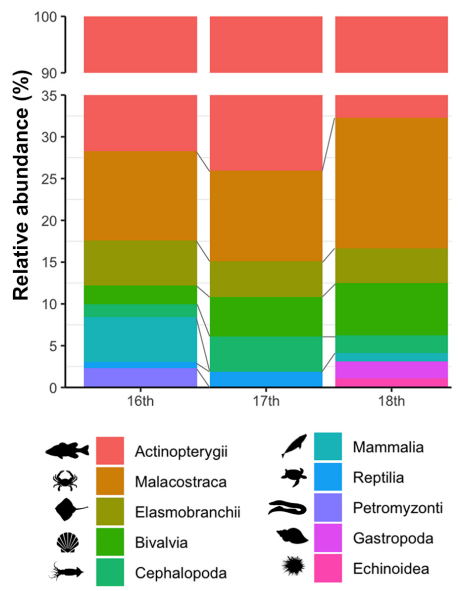

b)

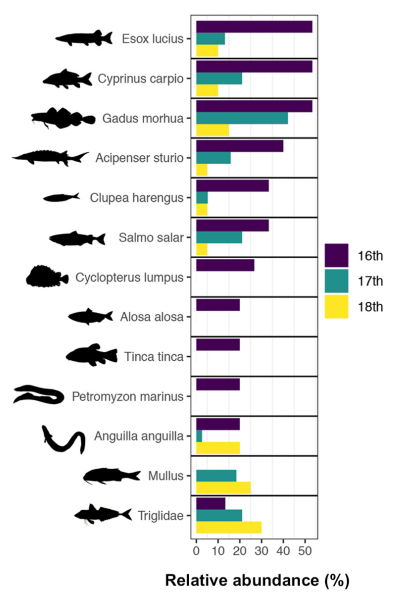

c)

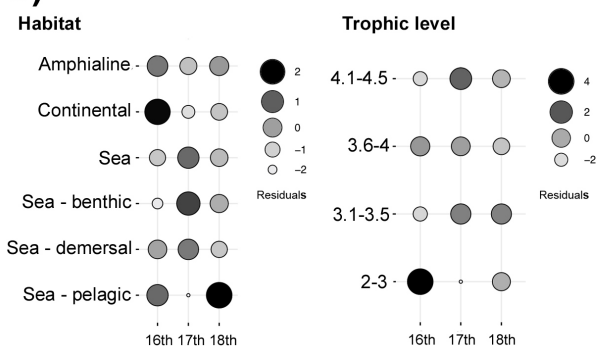

(Jacob Van Toorenvliet, A Fish Seller, 17th c.) for axis 2 (31.01\% of explained variance).

\section{DISCUSSION}

The paintings selected for our study belong to two regions and three periods. The Mediterranean paintings date mainly from the 18th century, whereas the Atlantic-North Sea paintings tend to date from the 16th and 17th centuries. Despite this unbalanced sample, the bias did not influence the homogeneity of taxa distribution across periods. However, taxa distribution across regions was significantly related to their Biogeographical Status and Habitat Group. This may mean that the places where taxa were painted are consistent with their natural ranges, suggesting that these works of art may provide reliable clues to inform about reference states of the past. 
Fig. 5. Distribution of selected taxa. (a) Principal component analysis (PCA) of the selected taxa represented in the paintings, showing that taxa are distributed in the paintings according to three distinct groups. Mul = Mullus, Mug = Mugilidae, Tri = Triglidae, Bel = Belone belone, Aci $=$ Acipenser sturio, Ang = Anguilla anguilla, Raj $=$ Rajidae, Ple. $1=$ Pleuronectidae, Cyc $=$ Cyclopterus lumpus, Can = Cancer pagurus, Hom = Homarus gammarus, Pet $=$ Petromyzon marinus, Gad $.1=$ Gadus morhua, Sals $=$ Salmo salar, $\mathrm{Mel}=$ Melanogrammus aeglefinus, $\mathrm{Clu}=$ Clupea harengus, $\mathrm{Abr}=$ Abramis brama, Eso $=$ Esox lucius, Per $=$ Perca fluviatilis, Cyp. 1 = Cyprinus carpio. (b) PCA across the two regions: each point corresponds to a painting, colored according to its geographical origin. (c) PCA across the three periods: each point corresponds to a painting, colored according to its period. For each PCA, only the first two dimensions are shown. The segmentation in space and time was given by confidence ellipses around barycenters at the $95 \%$ level.

a)

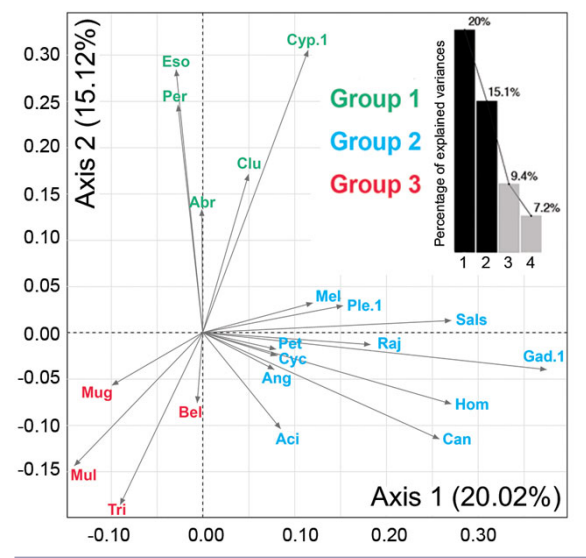

b)

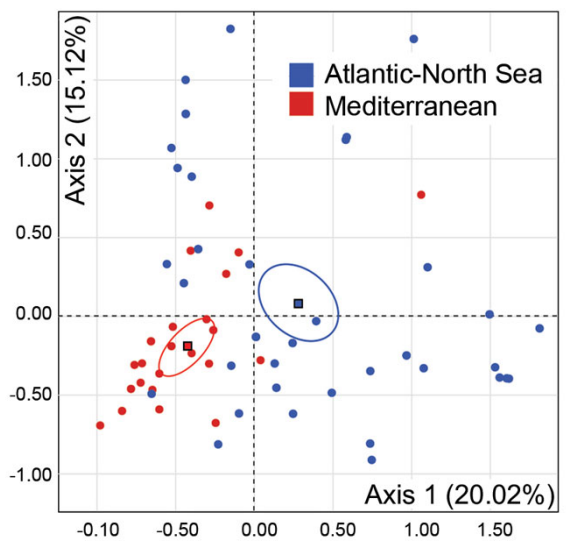

c)

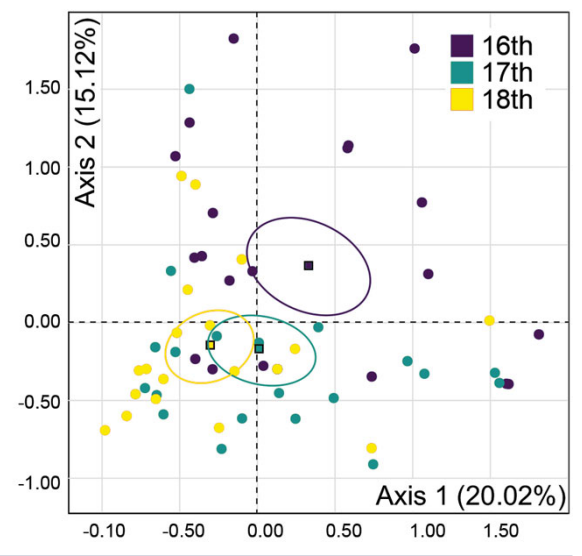

Following the purpose of this article, we investigated the significance of aquatic biodiversity representations from ecological and historical points of view. To determine historical significance, we divided the interpretations of variations using two "sieves": a technical one (determined by fishing techniques, aquaculture and transport), and a socio-cultural one (derived from food preferences and aesthetic choices). To address ecological significance, we took into account ecosystem variations in relation with the biogeography of the species and trends in population changes.

\section{Sorting taxa using technical sieves}

\section{Transport and conservation}

We have identified three types of containers used for the transport of fish: wooden barrels, wicker baskets, and tanks. Conditioned fish was transported in wooden barrels after being salted, smoked, or dried (Hoffman 2000). Barrels had been used since the Middle Ages and were primarily dedicated to salted salmon, dried cod, and brine herring. Thanks to this method, these species were widely transported and were consumed inland despite having been caught at sea (Hoffman 2005, Barrett et al. 2008). Such a barrel is visible in Appendix 3b ("Nature morte aux poissons", Unknown artist, Musée maritime de l'île Tatihou, Conseil départemental de la Manche). The fresh and live fish were transported in tanks, as can be seen in the painting at the bottom of Fig. 1. Tanks had also been used for this purpose since the Middle Ages, and were generally dedicated to the transport of freshwater species inland (Hoffman 2005), as is visible in the painting in Fig. 1. Note that these tanks are represented in $30 \%$ of the selected paintings. Wicker baskets were also used to transport fresh fish from the coasts to inland areas, as is visible in Appendix 3a ("Still life with fish", Abraham van Beyeren 1655,
RISD museum). The baskets were lined with straw to improve the conservation of the fish during transport by horse or donkey (Robert 2018).

In our results, the depicted taxa whose biogeography did not converge with the region in which they were painted provide a clue for the identification of transported species. This is the case for herring, whose representation is related to freshwater species (Group 1). Because herring was widely consumed inland from the Middle Ages on (Robert 2018), we find it depicted as being transported as fresh fish in tanks or baskets (Duhamel du Monceau and La Marre 1772), and as traveling at the same time as freshwater fish.

In the Mediterranean, the transport of oysters and shellfish started in the 17 th century, in particular, oysters from Tuscany (Italy), which were renowned for their quality. Oyster spat was also transported from Corsica, and from Livorno (Italy) where it was cultivated for the Grand Duchy of Tuscany. The transport of shellfish and oysters developed further during the 18th century with design improvements to the "Chasse-marées" vessels (Faget 2017).

Regardless of region, we observed that the representation of Malacostracans (i.e., crustaceans) increased sharply beginning in the 18 th $\mathrm{c}$. We believe that this phenomenon is linked to the improvement of transport conditions that facilitated the trade, and therefore the consumption, of crustaceans throughout Europe.

\section{Fishing techniques}

Fishing gear is an important sieve that probably influenced the abundance of depictions of specific taxa. This is particularly true for Mediterranean Sea Mullidae (red mullets) and Triglidae 
(gurnards), which were specifically targeted as benthic species using the first trawling methods that appeared in the 15th century (Faget 2017). Indeed, important changes appeared in the Mediterranean beginning in the 15 th century, characterized by innovations in fishing gear such as the Sardinal drift net (designed to catch small pelagic fishes), the Tartane trawlers (adapted to high seas fishing), longlines beginning in the late 15th century, and trawls towed by two vessels ("au boeuf" fishing) from the 18th century on (De Nicolò 2012, Faget 2015, 2017). This could explain the increasing frequency of depiction of these species during the studied period. In our study we highlight a tendency toward pelagic fishing in the Mediterranean. This may be related to the development of tuna traps in the $17 \mathrm{th} \mathrm{c}$. and Sardinal drift nets in the 15th c., both of which targeted pelagic fishes. During this period, the consumption of pelagic fish was characteristic of the diet of Mediterranean peoples (Faget 2017). Finally, the increase in the depiction of oysters (classified among the bivalves in our study) during this period may be related to the development of oyster harvesting in the Mediterranean in the 17th c., when metal dredges replaced hand gathering in shallow water (Faget 2017).

This period is characterized by a general improvement in both Atlantic and North Sea shipping and fishing techniques, such as bottom trawlers, drift nets, and gill nets (Pitcher and Lam 2015), leading to the development and occasional collapse of specific local fisheries. These events were particularly recorded for cod, herring, and sturgeon fisheries, and have been the subject of reviews by Poulsen (2008), Pitcher and Lam (2015), and Lenders (2017).

\section{Aquaculture}

Other technical sieves that deserve mention concern the introduction and culture of species. In the Mediterranean, oyster culture began in Livorno (Italy) in the 18th century but remained peripheral. The practice consisted of introducing spat into ponds in order to later harvest the adult oysters (Faget 2017). Further north, the Portuguese oyster (Crassostrea angulata, Lamarck 1819) was introduced into the North East Atlantic from Asia in the 16th century (Grade et al. 2016), where it replaced harvests of the indigenous flat oyster (Ostrea edulis, Linnaeus 1758). Oyster culture began in the 17 th century but remained peripheral until the 19th c (Buestel et al. 2009). Flat oysters appear in the selected 16th century paintings. It must be noted that differentiating between the Portuguese oyster and the flat oyster, as depicted in a painting, is not always possible. For example, in "La Raie" by Pierre-Siméon Chardin (1728, Louvre Museum) the experts we consulted could not identify with certainty the species of oyster represented. Another example of early aquaculture is the case of the common carp, which was raised inland in fishponds as early as the 12th c. (Hoffman 1995), meeting the needs of fresh fish in areas far from sea.

\section{Sorting taxa using socio-cultural sieves}

\section{Food preference}

Taxa whose natural distribution is European, but whose representation occurs mainly in paintings from a specific region, may indicate a culinary preference. For instance, taxa from Group 3 include European species that are strongly represented in Mediterranean paintings: grey mullet (Mugilidae), red mullet (Mullidae), and garfish (Belone belone, Linnaeus 1761). These are emblematic species of the Mediterranean. In particular, grey mullet are directly linked to the regional cultural identity, are consistently present in brackish water, and are easy to catch (De Nicolò 2019). Seabass (Dicentrarchus labrax, Linnaeus 1758) and squid (Loligo spp.) may also be associated with Mediterranean culinary preferences.

We observed a variation in the trophic levels of represented fishes: they remained low during the 16 th $\mathrm{c}$. then increased throughout the 17 th and 18 th centuries. We hypothesize that this variation is connected to the beginning of standardizations in food preferences, and to an increase in the diversity of depicted species.

\section{Religious precepts}

Regarding the effect of religious precepts on fish consumption, a major event was the Council of Trent (1545-1563) in response to the Protestant Reform, for it reaffirmed the dietary rules of the Church: meat consumption was forbidden for roughly 130 days $(35 \%)$ of the year, during which time only fish could be eaten. This led to an increase in the consumption of freshwater species such as pike (Esox lucius), common carp, salmon, and sturgeon (Acipenser sturio, Linnaeus 1758). Although these fish were already widely consumed in the Middle Ages (Hoffman 2005), this particular increase occurred in the period corresponding to the beginning of our study.

\section{Aesthetics}

The first paintings in our study date from the 16 th $\mathrm{c}$. This period corresponds to the European Renaissance, a movement that began in Italy in the 14th century and then spread throughout European art, especially through the Mannerist style. The Italian Renaissance masters greatly influenced the painters of Germany and the Netherlands during the 16th c. (Gombrich et al. 1997). The 17th c. was characterized by Baroque art in Italy, which also influenced Flemish artists who adopted a more demonstrative Baroque style. During the same period, Dutch painters developed the portrait and the landscape, with the objective of faithfully reproducing nature (in particular through still life works of art). We found a predominance of paintings of still lifes, and particularly of fish stalls, in our study. This kind of painting generally depicts an activity, which may be a practice, or even a profession (Blanchard 1981). Here, the activities highlighted are fishing, the preservation and transport of fish, the sale of fishery products at market, and their consumption. This suggests that the species represented are all intended to be eaten. The goal was not to represent the aquatic fauna in a systematic way, but rather to highlight the fish as food, surrounded by all the related activities and protagonists. These paintings therefore provide direct information about these practices. Concerning the other living creatures that figure in the paintings, human beings are predominant (37\% of the selected paintings) and are often portrayed as fish sellers or customers. Cats and dogs are also depicted alongside the humans, either through their predatory instinct (cats stealing food) or because they are privileged companions (dogs lying close to humans, or chasing a thieving cat).

A question that arises concerns other species such as whales and other large marine mammals, which are known to have been consumed, but do not appear in the paintings. These species were widely consumed in Europe from the 13th c. (Brito et al. 2019), and yet are not represented in any known painting. Our hypothesis 
is linked to the large size of these animals, which, because of the constraints of the still life genre, makes them poorly adapted as subjects.

Furthermore, we propose that certain species were depicted in the compositions not only because they were to be consumed, but also for their aesthetic qualities. For instance, salmon is often represented sliced, yet was surely not the only species that was transformed before being sold. We suggest that the orange color of the salmon flesh would have appealed to the painters as a means of bringing color to their compositions, and this regardless of the palatability of the fish. For example, a cock salmon (a male with breeding colors and a long, hooked jaw) is represented in a painting by Frans Snyders (Fig. 1) despite these fish rarely being consumed because of their inferior taste. Its presence in the painting may therefore be explained by the artist's desire to paint a fish with bright colors and an unusual shape. Indeed, painters did not always present market stalls with realism, but often constructed assemblies of different species, which were observed and studied separately by the artist. They sometimes added exotic species to their compositions, perhaps because of their aesthetic attributes. This is particularly true for the "Cabinet of Curiosities." However, because we chose to remove paintings representing species coming from worldwide collections, this type of sieve does not appear in our analyses.

Likewise, some species are not depicted in painting despite being widely consumed, perhaps because of a lack of artistic appreciation. For instance, although the depiction of cod decreased from the 16 th to the 18 th centuries, it was consumed with increasing regularity (Pitcher and Lam 2015). We suggest that the conservation method for cod transport played a role here, and that thanks to the improvement of transport conditions in the 17 th c., the cod arrived to market soon after being salted, dried, and stored in piles. It would therefore have been less recognizable as cod, and therefore less represented by painters. Finally, although this is not the subject of our study, a more indepth analysis is necessary to better explain the aesthetic choices of the painters and the possible symbolic dimensions of the species represented.

\section{Environmental and human pressures}

\section{Climate}

The studied period (16th-18th c.) is well documented regarding major climate changes that influenced the geographical distribution of aquatic species. For instance, the Little Ice Age (early 14th to late 19th c.) varied the biomass of certain species fished on European coasts, in particular cod and herring (Øiestad 1994, Holm et al. 2019). This phenomenon, combined with the improvement of fishing techniques and local social and political events, led to stock changes for several taxa. For instance, RavierMailly and Fromentin (2003) found evidence of negative correlations between bluefin tuna (Thunnus thynnus, Linnaeus 1758) catches and temperature in the 17 th c. Other evidence indicates that episodes of "sterility" (i.e., the temporary weakening of the biomass of certain species fished on the coasts) occurred in the 18th c. in the Gulf of Marseille and coincided with periods of excessively cold winters (Faget 2010). Conversely, the Little Ice Age had positive effects on specific populations such as sturgeon (Acipenser oxyrinchus, Mitchill 1815), which is a coldadapted species that migrated into the Baltic Sea, taking advantage of a weakening of the population of the more cold water-sensitive A. sturio (Tiedemann et al. 2007). Further north, cooler periods had a positive impact on herring populations in the Atlantic during the late 17th c. (Southward et al. 1988).

\section{Habitat modifications}

Important habitat modifications that occurred in European inland lakes and rivers also led to the decline of many fish populations (Lotze 2007). For instance, the practice of maintaining ponds for harvesting freshwater fish began to be questioned at the end of the 18th c., for these facilities reduced the area available for the cultivation of cereals, and were also considered to be unhealthy (Abad 2006). European countries therefore undertook the draining of these ponds, encouraged by the centralized monarchical states and the declining influence of the monks who had previously maintained a large number of the ponds (Morera 2011). This resulted in a decrease of northern pike (Nilsson et al. 2014) and other pond species such as common carp, perch (Perca fluviatilis), and bream (Abramis brama). Other preindustrial societal activities in and along rivers, such as wood rafting or the generation of hydropower using watermills, modified fish habitats and impacted spawning grounds, eggs, larvae, and juvenile fish survival (Haidvogl et al. 2014). The expansion of watermill technology across Europe had a great impact on salmon populations between the Early Middle Ages and Early Modern Times (16th c.; Lenders et al. 2016). In addition, the channeling of European waterways began in the 17 th c. in the Netherlands as a remedy for mobility shortcomings (Brolsma et al. 2011).

The pollution of waterways linked to the artisanal or industrial activities of the 18th c. may also have affected freshwater fish populations. Waterways close to cities were seen to be pestilential and dangerous, and the link between artisanal or industrial activities and insalubrity was well established (Le Roux 2011). Pre-industrial mining and metallurgy also had a great impact on lakes and rivers from the 16th to 18th centuries (Bindler et al. 2009, Haidvogl 2018).

\section{Fish populations}

The set of paintings reveals that the natural range of species is mainly convergent with the place they were painted. This is particularly true for the Atlantic-North Sea taxa (Group 2) that are adapted to cold water. For instance, S. salar, G. morhua, and C. harengus are exclusively present in the Atlantic Ocean. Likewise, edible crab (Cancer pagurus, Linnaeus 1758) and European lobster (Homarus gammarus, Linnaeus 1758) are rarely found in the Mediterranean, and are mainly represented in works painted in the Atlantic-North Sea. In the Mediterranean, we can cite Mantis shrimp (Squilla mantis, Linnaeus 1758) whose exclusive representation in the Mediterranean converges with its natural biogeography.

\section{Examples of combined effects on documented species}

Although the geographical distribution of species remains constant, the abundance of populations vary over the three centuries. These variations are primarily related to diverse human activities.

The most striking examples are the sturgeon, herring and cod. For example, sturgeon (A. sturio) populations were threatened by climate, fishing, and anthropic habitat modification from the 12 th 
c. and from Italy to the Baltic (Hoffman 2005, Tiedemann et al. 2007). The Danube River sturgeon population, in particular, decreased in the 16th century (Guti 2008). North Sea herring fisheries were shaped by a combination of political, social, economic, and environmental factors between the 16th and 18th centuries (Poulsen 2008), and the expansion in the late 17th c. of the salted barrel herring trade operated by drift net fisheries in the North Sea is thought to have led to the serial collapse of inshore herring stocks (Pitcher and Lam 2015). Thus, complaints by fishers of depleted stocks became more frequent (Thurstan et al. 2014). In addition, the environmental history of Atlantic fisheries exhibits a series of local depletions and shifts in local fish communities (Bolster 2012). The discovery of the Grand Banks off Newfoundland, Canada in the late 15th c. allowed the exploitation of huge cod populations, and the technological improvements of the following century led to a rapid expansion of catches (Pitcher and Lam 2015).

Reductions in the distribution of anadromous fishes such as sturgeon and salmon were also reported in Europe from the Middle Ages to Early Modern times, probably because of the combined effects of fisheries pressure (especially for sturgeons, which are estuarine fish caught at shallow depth with gillnets) and of pollution, habitat modification, and climate (Hoffman 2005, Tiedemann et al. 2007, Guti 2008, Lenders et al. 2016). All of these factors are clearly convergent with the diminishing number of depictions of freshwater and amphihaline migratory species in the paintings in our study.

\section{CONCLUSION}

This study highlights both the natural and the anthropic factors that shaped the spatial and temporal variations of aquatic species prior to Modern times in Western Europe. Although it is difficult to fully disentangle what relates to historical or ecological events, significant trends have been identified. The most obvious is that the fish represented in European paintings from the 16th to 18th centuries belong to two regions and three periods, which can be statistically discriminated. All represented taxa were intended for food and thus imply links to fishing and transport techniques. However, we illustrate that there are also environmental and sociocultural factors that should be taken into account. Regarding spatial variations, our results strongly suggest that there is a convergence between the origin of the paintings and the biogeographic area of the species that are represented. This confirms the objective of the study and the validity of the method used to inform the evolution of aquatic socio-ecosystems. Concerning temporal variations, we found an overall decrease of represented taxa and particularly of continental and freshwater species. Thanks to previous work showing that human impacts on freshwater ecosystems had already begun in the Middle Ages, we conclude that tendencies observed in our study are the result of these earlier changes. This demonstrates the importance of including marine and freshwater species (consumed both on the coast and inland), rather than using a segmenting approach to marine and freshwater environments. On the other hand, we also observed an increase in representations of pelagic species, Malacostraca and Bivalvia, which is probably more closely linked to developments in fishing and transport.

These observations are corroborated by the works cited above, to which we have added a series of hypotheses concerning the effects of mixing environmental variations, technical sieves, and sociocultural sieves. It is not possible to precisely quantify the effect of any one of these factors on the depicted species, however they do open up interesting fields of investigation. For instance, to our knowledge, no meta-analysis of archaeological data on the Mediterranean aquatic species has been undertaken. There is thus a real need to integrate archeology into Mediterranean historical ecology studies. In terms of aesthetic interpretation, it is necessary to investigate the career and influences of each painter from an art history angle. Increasing the number of paintings studied would also provide more knowledge. Concerning taxa identification, some require more precise specification, e.g., pikes, shads, sturgeons, loligos, octopus, oysters, and urchins, in the search for disappeared, introduced, or recently detected species, e.g., the three species of pikes in France (Denys et al. 2014). In addition, there is a shift between poorly documented species and highly informed commercial species, e.g., sturgeon, herring, and cod, which needs to be rebalanced. This article constitutes an encouraging first step toward the emergence of multidisciplinary methodologies intended to better understand the past reference state of aquatic socio-ecosystems, using an integrative approach.

Responses to this article can be read online at: https://www.ecologyandsociety.org/issues/responses. $\mathrm{php} / 12740$

\section{Acknowledgments:}

Taxa identification was carried out by Mireille and Jean-Georges Harmelin, Sébastien Biton, Marine Briand, Mélanie Ourgaud, and Sandrine Ruitton from the Mediterranean Institute of Oceanography (Marseille, France), Laurence Le Diréach, Patrick Astruc, Adrien Goujard, and Elodie Rouanet from the "Groupement d'Intérêt Scientifique” (GIS) POSIDONIE (Marseille, France), Gaël Denys and Caroline Mougne from the National Museum of Natural History (Paris, France), Catherine Dupont from the CNRS, UMR CReAAH (Rennes, France), and Yves Gruet (retired), from the University of Nantes (France). We would like to thank the fine arts and archeology museums, which responded positively to our request for the complete identification of the species in our selection of paintings: Musée du Louvre de Paris, France, Musée d'Orsay de Paris, France, Musée des Beaux-Arts de Rouen, France, Musée Saint-Loup de Troyes, France, Musée des BeauxArts de Caen, France, Musée d'Art et d'Archéologie de Senlis, France, Musée Condé de Chantilly, France, Musée de Boulognesur-Mer, France, Musée Quentovic d'Etaples, France, Musée Sandelin de St-Omer, France, Musée d'Archéologie d'Antibes, France, Musée dArt Moderne André Malraux du Havre, France, Musée Picasso de Paris, France, Museu Nacional d'Art de Catalunya, Spain, Museo Bellas Artes de Sevilla, Spain, Museu de Belles Arts de Valencia, Spain, Gallerie dell'Accademia di Venezia, Italia, the Rhode Island School of Design Museum, USA, and the Metropolitan Museum of Art of New York, USA. We specifically thank Philippe Costamagna, Director of Musée Fesch d'Ajaccio, France, and Annick Lemarrec, librarian for the same museum, for specific information on the painter Alessandro Di Pesci. We finally 
thank the State Hermitage Museum of St-Petersburg, Russia, the Rhode Island School of Design Museum, USA, and the Musée Maritime de l'Ile Tatihou, France, for their permission to publish paintings from their collections. The study was funded by the Fond Epicurien de Provence, by the French ECCOREV (Continental Ecosystems and Environmental Risks) Research Federation, by the Excellence Initiative of Aix-Marseille University - $A^{*}$ Midex, a French "Investissements d'Avenir programme" AMX-19-IET-012 through the Mediterranean Institute for the Environmental Transition ITEM, by the Rhône Mediterranean Corsica Water Agency (Pierre Boissery, Agence de l'Eau Rhône-MediterranéeCorse), and by the Fondation de France through the programme "Quels littoraux pour demain?."

\section{Data Availability:}

The data that support the findings of this study are openly available in figshare at https://10.6084/m9. figshare.14035202.

\section{LITERATURE CITED}

Abad, R. 2006. La conjuration contre les carpes: enquête sur les origines du décret de dessèchement des étangs du 14 frimaire an II. Fayard, Paris, France.

Barrett, J., C. Johnstone, J. Harland, W. Van Neer, A. Ervynck, D. Makowiecki, D. Heinrich, A. K. Hufthammer, I. B. Enghoff, C. Amundsen, J. S. Christiansen, A. K. G. Jones, A. Locker, S. Hamilton-Dyer, L. Jonsson, L. Lõugas, C. Roberts, and M. Richards. 2008. Detecting the medieval cod trade: a new method and first results. Journal of Archaeological Science 35(4):850-861. https://doi.org/10.1016/j.jas.2007.06.004

Begossi, A., and R. Caires. 2015. Art, fisheries and ethnobiology. Journal of Ethnobiology and Ethnomedicine 11(1):16. https:// doi.org/10.1186/1746-4269-11-17

Bénézit, E. 2006. Dictionary of artists. Art Libraries Journal 32 (2):45-46.

Bianchi, C. N., and C. Morri. 2000. Marine biodiversity of the Mediterranean Sea: situation, problems and prospects for future research. Marine Pollution Bulletin 40(5):367-376. https://doi. org/10.1016/S0025-326X(00)00027-8

Bindler, R., I. Renberg, J. Rydberg, and T. Andrén. 2009. Widespread waterborne pollution in central Swedish lakes and the Baltic Sea from pre-industrial mining and metallurgy. Environmental Pollution 157(7):2132-2141. https://doi.org/10.1016/ j.envpol.2009.02.003

Blanchard, M.-E. 1981. Natures mortes. Communications 34 (1):41-60. https://doi.org/10.3406/comm.1981.1507

Bolster, W. J. 2012. The mortal sea. Harvard University Press, Cambridge, Massachusetts, USA. https://doi.org/10.4159/ harvard.9780674067219

Boudouresque, C.-F. 2004. Marine biodiversity in the Mediterranean: status of species, populations and communities. Scientific Reports of Port-Cros National Park, France 20:97-146.

Brito, C., N. Vieira, and J. G. Freitas. 2019. The wonder whale: a commodity, a monster, a show and an icon. Anthropozoologica 54(1):13-27. https://doi.org/10.5252/anthropozoologica2019v54a3
Brolsma, J. U., Rijkswaterstaat Dienst Verkeer en Scheepvaart, and Afdeling Netwerken Ontwerp en Inrichting. 2011. Richtlijnen vaarwegen 2011: RVW 2011. Rijkswaterstaat, Den Haag, The Netherlands.

Buestel, D., M. Ropert, J. Prou, and P. Goulletquer. 2009. History, status, and future of oyster culture in France. Journal of Shellfish Research 28(4):813-820. https://doi.org/10.2983/035.028.0410

Burroughs, W. J. 1981. Winter landscapes and climatic change. Weather 36(12):352-357. https://doi.org/10.1002/j.1477-8696.1981. tb05362.x

Charmantier, G. 2014. Crustaceans in art. Pages 139-187 in J. C. von Vaupel Klein, editor. Treatise on zoology - anatomy, taxonomy, biology. The Crustacea, Volume 4 Part B. Brill, Leiden, The Netherlands. https://doi.org/10.1163/9789004264939005

Cleyet-Merle, J.-J. 1990. La préhistoire de la pêche. Errance, Paris, France.

Coll, M., C. Piroddi, J. Steenbeek, K. Kaschner, F. Ben Rais Lasram, J. Aguzzi, E. Ballesteros, C. N. Bianchi, J. Corbera, T. Dailianis, R. Danovaro, M. Estrada, C. Froglia, B. S. Galil, J. M. Gasol, R. Gertwagen, J. Gil, F. Guilhaumon, K. Kesner-Reyes, M.-S. Kitsos, A. Koukouras, N. Lampadariou, E. Laxamana, C. M. López-Fé de la Cuadra, H. K. Lotze, D. Martin, D. Mouillot, D. Oro, S. Raicevich, J. Rius-Barile, J. I. Saiz-Salinas, C. San Vicente, S. Somot, J. Templado, X. Turon, D. Vafidis, R. Villanueva, and E. Voultsiadou. 2010. The biodiversity of the Mediterranean Sea: estimates, patterns, and threats. PLoS ONE 5(8):e11842. https://doi.org/10.1371/journal.pone.0011842

De Nicolò, M. L. 2012. Recherches sur l'histoire de la pêche en Méditerranée : tartanes de Provence, tartanes de Vénétie, trabacs, modèles adriatiques pour la pêche à la traîne et le petit cabotage. Cahiers de la Méditerranée 84:309-323.

De Nicolò, M. L. 2019. Pesce bianco, pesce rosa. Cefalo e Fragolino: storia, produzione, tradizioni alimentari. Organizzazione produttori pesca di Fano, Marotta e Senigallia, Italy. ISBN: 978-88-95665-30-6.

De Vries, J. 1994. Population. Pages 25-50 in T. A. Brady, H. A. Oberman, and J. D. Tracy, editors. Handbook of European history 1400-1600: Late Middle Ages, Renaissance and Reformation. Brill, Leiden, The Netherlands. https://doi. org/10.1163/9789004391659 002

Delorme, J. 1987. Guide illustré de la faune aquatique dans l'art grec. Association pour la promotion et la diffusion des connaissances archéologiques, Juan-les-Pins, France.

Denys, G. P. J., A. Dettai, H. Persat, M. Hautecoeur, and P. Keith. 2014. Morphological and molecular evidence of three species of pikes Esox Spp. (Actinopterygii, Esocidae) in France, including the description of a new species. Comptes Rendus Biologies 337 (9):521-534. https://doi.org/10.1016/j.crvi.2014.07.002

Duhamel du Monceau, H.-L., and L. H. de La Marre. 1772. Traité général des pesches et histoire des poissons qu'elles fournissent. Saillant\&Nyon, Paris, France.

Faget, D. 2010. Une histoire du milieu marin méditerranéen. Le cas du golfe de Marseille (XVIIIe - XIXe siècles): sources et approches pluridisciplinaires. Rives méditerranéennes 139-154. https://doi.org/10.4000/rives.3954 
Faget, D., editor. 2015. Pêches méditerranéennes: origines et mutations protohistoire-XXIe siècle. Karthala, Paris, France.

Faget, D. 2017. L'écaille et le banc: ressources de la mer Méditerranée moderne: XVIe-XVIIIe siècle. Presses universitaires de Provence, Aix-en-Provence, France. https://doi.org/10.4000/ books.pup. 45283

Fontaine-Bayer, L. 1993. Le Chasse-marée de Picardie sur la route du poisson. Dumerchez, Creil, France.

Fortibuoni, T., S. Libralato, S. Raicevich, O. Giovanardi, and C. Solidoro. 2010. Coding early naturalists' accounts into long-term fish community changes in the Adriatic Sea (1800-2000). PLoS ONE 5(11):e15502. https://doi.org/10.1371/journal.pone.0015502

Goddeeris, B., G. De Smet, and W. Roggeman. 2002. Some gastronomic aspects of bird species in still life paintings of Frans Snyders (Antwerp, 1579-1657). Revue belge de philologie et d'histoire 80(4):1431-1448. https://doi.org/10.3406/rbph.2002.4678

Gombrich, E. H., J. Combe, C. Lauriol. 1997. Histoire de l'art. Nouv. éd. rev. et augm. Gallimard, Paris, France. ISBN: 2070115631

Grade, A., H. Chairi, D. Lallias, D. M. Power, F. Ruano, A. Leitão, T. Drago, J. W. King, P. Boudry, and F. M. Batista. 2016. New insights about the introduction of the Portuguese oyster, Crassostrea angulata, into the North East Atlantic from Asia based on a highly polymorphic mitochondrial region. Aquatic Living Resources 29(4):404. https://doi.org/10.1051/alr/2016035

Guidetti, P., and F. Micheli. 2011. Ancient art serving marine conservation. Frontiers in Ecology and the Environment 9 (7):374-375. https://doi.org/10.1890/11.WB.019

Guti, G. 2008. Past and present status of sturgeons in Hungary and problems involving their conservation. River Systems 18 (1-2):61-79. https://doi.org/10.1127/1r/18/2008/61

Haidvogl, G. 2018. Historic milestones of human river uses and ecological impacts. Pages 19-39 in S. Schmutz and J. Sendzimir, editors. Riverine ecosystem management: science for governing towards a sustainable future. Springer International, Cham, Switzerland. https://doi.org/10.1007/978-3-319-73250-3 2

Haidvogl, G., D. Lajus, D. Pont, M. Schmid, M. Jungwirth, and J. Lajus. 2014. Typology of historical sources and the reconstruction of long-term historical changes of riverine fish: a case study of the Austrian Danube and northern Russian rivers. Ecology of Freshwater Fish 23(4):498-515. https://doi. org/10.1111/eff.12103

Hoffman, R. C. 1995. Environmental change and the culture of common carp in medieval Europe. Guelph Ichtyology Reviews 3:57-85.

Hoffman, R. C. 2000. Medieval fishing. Pages 331-393 in P. Squatriti, editor. Working with water in Medieval Europe: technology and resource-use. Brill, Leiden, The Netherlands. https://doi.org/10.1163/9789047400110 012

Hoffman, R. C. 2005. A brief history of aquatic resource use in medieval Europe. Helgoland Marine Research 59(1):22-30. https://doi.org/10.1007/s10152-004-0203-5
Holm, P., F. Ludlow, C. Scherer, C. Travis, B. Allaire, C. Brito, P. W. Hayes, J. A. Matthews, K. J. Rankin, R. J. Breen, R. Legg, K. Lougheed, and J. Nicholls. 2019. The North Atlantic fish revolution (ca. AD 1500). Quaternary Research 1-15. https://doi. org/10.1017/qua.2018.153

Jackson, J. B. C., M. X. Kirby, W. H. Berger, K. A. Bjorndal, L. W. Botsford, B. J. Bourque, R. H. Bradbury, R. Cooke, J. Erlandson, J. A. Estes, et al. 2001. Historical overfishing and the recent collapse of coastal ecosystems. Science 293(5530):629-637. https://doi.org/10.1126/science.1059199

Keith, P., N. Poulet, G. Denys, T. Changeux, É. Feunteun, and H. Persat. 2020. Les poissons d'eau douce de France. Muséum national d'histoire naturelle. Inventaire et biodiversité. Biotope Editions (Mèze), Paris, France.

Lamb, H. H. 1967. Britain's changing climate. Geographical Journal 133(4):445-466. https://doi.org/10.2307/1794473

Lê, S., J. Josse, and F. Husson. 2008. FactoMineR: An R Package for Multivariate Analysis. Journal of Statistical Software 25(1) 1-18. https://doi.org/10.18637/jss.v025.i01

Le Roux, T. 2011. Le Laboratoire des pollutions industrielles. Paris, 1770-1830. Albin Michel, Paris, France.

Le Roy Ladurie, E. 1993. Histoire du climat depuis l'an mil Premier volume. Flammarion, Paris, France.

Lenders, H. J. R. 2017. Fish and fisheries in the Lower Rhine 1550-1950: a historical-ecological perspective. Journal of Environmental Management 202:403-411. https://doi.org/10.1016/ j.jenvman.2016.09.011

Lenders, H. J. R., T. P. M. Chamuleau, A. J. Hendriks, R. C. G. M. Lauwerier, R. S. E. W. Leuven, and W. C. E. P. Verberk. 2016. Historical rise of waterpower initiated the collapse of salmon stocks. Scientific Reports 6(1):29269. https://doi.org/10.1038/ srep29269

Liquete, C., C. Piroddi, E. G. Drakou, L. Gurney, S. Katsanevakis, A. Charef, and B. Egoh. 2013. Current status and future prospects for the assessment of marine and coastal ecosystem services: a systematic review. PLoS ONE 8(7):e67737. https://doi. org/10.1371/journal.pone.0067737

Longhurst, A. R. 2007. Ecological geography of the sea. Second edition. Academic, Amsterdam, The Netherlands. https://doi. org/10.1016/B978-0-12-455521-1.X5000-1

Lotze, H. K. 2007. Rise and fall of fishing and marine resource use in the Wadden Sea, southern North Sea. Fisheries Research 87(2-3):208-218. https://doi.org/10.1016/j.fishres.2006.12.009

Lotze, H. K., M. Coll, and J. A. Dunne. 2011. Historical changes in marine resources, food-web structure and ecosystem functioning in the Adriatic Sea, Mediterranean. Ecosystems 14 (2):198-222. https://doi.org/10.1007/s10021-010-9404-8

McClenachan, L. 2009. Documenting loss of large trophy fish from the Florida Keys with historical photographs. Conservation Biology 23(3):636-643. https://doi.org/10.1111/j.1523-1739.2008.01152. $\underline{\mathrm{X}}$

McPhee, I., and A. D. Trendall. 1987. Greek red-figured fishplates. Vereinigung der Freunde Antiker Kunst c/o 
Archäologisches Seminar der Universität, Basel, Switzerland. ISBN: 978-3-909064-14-4.

Metzger, H. 1990. Les images de faune aquatique et marine dans l'art Grec. Revue des Études Grecques 103(492/494):673-683. https://doi.org/10.3406/reg.1990.2493

Morera, R. 2011. L'assèchement des marais: en France au XVIIe siècle. Presses universitaires de Rennes, Rennes, France. https:// doi.org/10.4000/books.pur.111444

Moyle, P. B., and M. A. Moyle. 1991. Introduction to fish imagery in art. Environmental Biology of Fishes 31(1):5-23. https://doi. org/10.1007/BF00002153

Neuberger, H. 1970. Climate in art. Weather 25(2):46-56. https:// doi.org/10.1002/j.1477-8696.1970.tb03232.x

Neuberger, H., and J. E. Thornes. 2005. Art and climate. Pages 94-102 in J. E. Oliver, editor. Encyclopedia of world climatology. Encyclopedia of Earth Sciences Series. Springer, Dordrecht, The Netherlands. https://doi.org/10.1007/1-4020-3266-8 18

Nilsson, J., O. Engstedt, and P. Larsson. 2014. Wetlands for northern pike (Esox lucius L.) recruitment in the Baltic Sea. Hydrobiologia 721(1):145-154. https://doi.org/10.1007/s10750-013-1656-9

Øiestad, V. 1994. Historic changes in cod stocks and cod fisheries: Northeast Arctic cod. ICES Marine Science Symposia 198:17-30.

Papworth, S. K., J. Rist, L. Coad, and E. J. Milner-Gulland. 2009. Evidence for shifting baseline syndrome in conservation. Conservation Letters 2(2):93-100. https://doi.org/10.1111/ j.1755-263X.2009.00049.X

Pauly, D. 1995. Anecdotes and the shifting baseline syndrome of fisheries. Trends in Ecology \& Evolution 10(10):430. https://doi. org/10.1016/S0169-5347(00)89171-5

Pitcher, T. J., and M. E. Lam. 2015. Fish commoditization and the historical origins of catching fish for profit. Maritime Studies 14(1):2. https://doi.org/10.1186/s40152-014-0014-5

Poulsen, B. 2008. Dutch herring: an environmental history, c. 1600-1860. Amsterdam University Press, Amsterdam, The Netherlands. https://doi.org/10.2307/j.ctt6wp5m2

Ravier-Mailly, C., and J.-M. Fromentin. 2003. Long-term fluctuations in bluefin tuna trap catches: are they environmentally driven? Collective Volume of Scientific Papers ICCAT 55 (3):1208-1216.

Robert, S. 2018. Les chasse-marée et la route du poisson: Réduire la distance pour approvisionner Paris du xiiie au xviiie siècle. Techniques \& Culture 69:132-135. https://doi.org/10.4000/ tc. 8943

Schmidt, S. N., C. J. Harvey, and M. J. Vander Zanden. 2011. Historical and contemporary trophic niche partitioning among Laurentian Great Lakes coregonines. Ecological Applications 21 (3):888-896. https://doi.org/10.1890/09-0906.1

Schwerdtner Máñez, K., G. Krause, I. Ring, and M. Glaser. 2014. The Gordian knot of mangrove conservation: disentangling the role of scale, services and benefits. Global Environmental Change 28:120-128. https://doi.org/10.1016/j.gloenvcha.2014.06.008
Southward, A. J., G. T. Boalch, and L. Maddock. 1988. Fluctuations in the herring and pilchard fisheries of Devon and Cornwall linked to change in climate since the 16th century. Journal of the Marine Biological Association of the United Kingdom 68(3):423-445. https://doi.org/10.1017/S0025315400043320

Szabó, P. 2015. Historical ecology: past, present and future. Biological Reviews 90(4):997-1014. https://doi.org/10.1111/ brv. 12141

Thurstan, R. H., J. P. Hawkins, and C. M. Roberts. 2014. Origins of the bottom trawling controversy in the British Isles: 19th century witness testimonies reveal evidence of early fishery declines. Fish and Fisheries 15(3):506-522. https://doi. org/10.1111/faf.12034

Tiedemann, R., K. Moll, K. B. Paulus, M. Scheer, P. Williot, R. Bartel, J. Gessner, and F. Kirschbaum. 2007. Atlantic sturgeons (Acipenser sturio, Acipenser oxyrinchus): American females successful in Europe. Naturwissenschaften 94(3):213-217. https:// doi.org/10.1007/s00114-006-0175-1

Tierno de Figueroa, J. M., M. J. López-Rodríguez, S. Fenoglio, P. Sánchez-Castillo, and R. Fochetti. 2013. Freshwater biodiversity in the rivers of the Mediterranean Basin. Hydrobiologia 719(1):137-186. https://doi.org/10.1007/s10750-012-1281Z

Tortonese, E. 1985. Distribution and ecology of endemic elements in the Mediterranean fauna (fishes and echinoderms). Pages 57-83 in M. Moraitou-Apostolopoulou and V. Kiortsis, editors. Mediterranean marine ecosystems. Springer U.S., Boston, Massachusetts, USA. https://doi.org/10.1007/978-1-4899-2248-9 4

Worm, B., E. B. Barbier, N. Beaumont, J. E. Duffy, C. Folke, B. S. Halpern, J. B. C. Jackson, H. K. Lotze, F. Micheli, S. R. Palumbi, E. Sala, K. A. Selkoe, J. J. Stachowicz, and R. Watson. 2006. Impacts of biodiversity loss on ocean ecosystem services. Science 314(5800):787-790. https://doi.org/10.1126/science.1132294 


\section{Appendix 1: Selected paintings}

\begin{tabular}{|c|c|c|c|c|c|c|}
\hline $\mathbf{N}^{\circ}$ & Period & Region & Country & Last name & First name & Title \\
\hline 1 & 16th & Mediterranean & Italy & Campi & Vincenzo & $\begin{array}{l}\text { Christ in the house of } \\
\text { Mary and Martha }\end{array}$ \\
\hline 2 & 16th & Mediterranean & Italy & Campi & Vincenzo & Fishmongers \\
\hline 3 & 16th & Mediterranean & Italy & Campi & Vincenzo & Fishmongers \\
\hline 4 & 16 th & Mediterranean & Italy & Bartolomeo & Passarotti & The Fish Stall \\
\hline 5 & 16th & Mediterranean & Italy & Arcimboldo & Guiseppe & Water \\
\hline 6 & 16th & Mediterranean & Italy & Bartolomeo & Passarotti & The Fishmongers \\
\hline 7 & 17 th & Mediterranean & Italy & Cornelisz & Pieter & $\begin{array}{l}\text { Kitchen scene with the } \\
\text { parable of the rich man and } \\
\text { Lazarus }\end{array}$ \\
\hline 8 & 17 th & Mediterranean & Italy & Cornelisz & Pieter & The Kitchen Maid \\
\hline 9 & 17 th & Mediterranean & Italy & Crivelli & Angelo & Nature morte aux poissons \\
\hline 10 & 17 th & Mediterranean & Italy & Recco & Giovanni Battista & $\begin{array}{l}\text { Nature morte aux poissons } \\
\text { de mer et aux huître } \\
\text { orientales }\end{array}$ \\
\hline 11 & 17 th & Mediterranean & Italy & Recco & Giuseppe & Nature morte aux poissons \\
\hline 12 & 17 th & Mediterranean & Italy & Recco & Elena & Poissons \\
\hline 13 & 17 th & Mediterranean & Italy & Recco & Giuseppe & Poissons de mer et crabes \\
\hline 14 & 17 th & Mediterranean & Italy & Recco & Giuseppe & $\begin{array}{l}\text { Poissons de mer et } \\
\text { coquillages }\end{array}$ \\
\hline 15 & 17 th & Mediterranean & Italy & Recco & Giuseppe & $\begin{array}{l}\text { Still life with fish and } \\
\text { a turtle }\end{array}$ \\
\hline 16 & 17 th & Mediterranean & Italy & Recco & Giuseppe & A cat stealing fish \\
\hline 17 & 17 th & Mediterranean & Italy & Recco & Giuseppe & $\begin{array}{l}\text { Nature morte aux poissons } \\
\text { et homard }\end{array}$ \\
\hline 18 & 17 th & Mediterranean & Italy & De Pesci & Alessandro & $\begin{array}{l}\text { Nature morte à la tortue } \\
\text { et poissons }\end{array}$ \\
\hline 19 & 17 th & Mediterranean & Italy & Cipper & Giacomo Francesco & Still life of fish and shellfish \\
\hline 20 & 17 th & Mediterranean & Italy & Toorenvliet & Jacob van & A fish seller \\
\hline 21 & 18 th & Mediterranean & Spain & Viladomat & Antonio & $\begin{array}{l}\text { Still life with shellfish, fish } \\
\text { and vessels }\end{array}$ \\
\hline 22 & 18th & Mediterranean & Marseille & Chasse & Barthélémy & La pêche miraculeuse \\
\hline 23 & 18 th & Mediterranean & Italy & Boselli & Felice & Divers poissons et araignées \\
\hline 24 & 18th & Mediterranean & Italy & Cerutti & Giacomo & $\begin{array}{l}\text { Nature morte avec des } \\
\text { poissons et des oignons }\end{array}$ \\
\hline 25 & 18th & Mediterranean & Italy & Cerutti & Giacomo & Hummer und Meeresfrüchte \\
\hline 26 & 18th & Mediterranean & Italy & Cerutti & Giacomo & Garçon au panier de poisson \\
\hline 27 & 18 th & Mediterranean & Italy & Crivelli & Angelo Maria & $\begin{array}{l}\text { Pesci e crostacei, con } \\
\text { marina lontananza }\end{array}$ \\
\hline 28 & 18 th & Mediterranean & Italy & Crivelli & Angelo Maria & Nature morte aux poissons \\
\hline 29 & 18 th & Mediterranean & Spain & Melendez & Luis & $\begin{array}{l}\text { Nature morte avec rousseaux } \\
\text { et oranges }\end{array}$ \\
\hline 30 & 16th & Atlantic - North Sea & Antwerp & Beuckelaer & Joachim & $\begin{array}{l}\text { Le marché aux poissons; } \\
\text { Marchands de poissons }\end{array}$ \\
\hline 31 & 16th & Atlantic - North Sea & Antwerp & Beuckelaer & Joachim & Les marchands de poissons \\
\hline 32 & 16 th & Atlantic - North Sea & Antwerp & Beuckelaer & Joachim & The Four Element: Water \\
\hline
\end{tabular}




\begin{tabular}{|c|c|c|c|c|c|}
\hline 17 th & Atlantic - North Sea & Netherlands & Wtewael & Joachim & $\begin{array}{l}\text { Kitchen interior with the } \\
\text { parable of the great supper }\end{array}$ \\
\hline 17 th & Atlantic - North Sea & Antwerp & Snyders & Frans & $\begin{array}{l}\text { Marchands de poissons } \\
\text { à leur étal }\end{array}$ \\
\hline 16th & Atlantic - North Sea & Antwerp & Snyders & Frans & The Fishmongers \\
\hline 17 th & Atlantic - North Sea & Antwerp & Snyders & Frans & Fish Stall \\
\hline 17 th & Atlantic - North Sea & Antwerp & Adriaenssen & Alexander & Nature morte aux poissons \\
\hline 17 th & Atlantic - North Sea & Antwerp & Adriaenssen & Alexander & Nature morte aux oiseaux \\
\hline 17 th & Atlantic - North Sea & Antwerp & Adriaenssen & Alexander & Un marchand de poissons \\
\hline 17 th & Atlantic - North Sea & Netherlands & Delff & Cornelis Jacobsz & Nature morte de cuisine \\
\hline 17 th & Atlantic - North Sea & Netherlands & Putter & Pierre de & $\begin{array}{l}\text { Tableau de pêche devant } \\
\text { un paysage }\end{array}$ \\
\hline 17 th & Atlantic - North Sea & Antwerp & Van Kessel 1 & Jan & Poissons \\
\hline 17 th & Atlantic - North Sea & Antwerp & Peeters & Clara & $\begin{array}{l}\text { Still life with fish, candle, } \\
\text { artichokes, crabs and schrimp }\end{array}$ \\
\hline 17 th & Atlantic - North Sea & Germany & Mignon & Abraham & $\begin{array}{l}\text { Still life with fruit, fish, } \\
\text { and a nest }\end{array}$ \\
\hline 17 th & Atlantic - North Sea & Antwerp & Adriaenssen & Alexander & $\begin{array}{l}\text { Still life with fish and } \\
\text { oysters }\end{array}$ \\
\hline 17 th & Atlantic - North Sea & Netherlands & Beyeren & Abraham van & The ray \\
\hline 17 th & Atlantic - North Sea & Netherlands & Beyeren & Abraham van & Still life with fish \\
\hline 17 th & Atlantic - North Sea & Netherlands & De Witte & Emanuel & The fish market at evening \\
\hline 17 th & Atlantic - North Sea & Netherlands & Ostade & Adriaen van & Fishwife \\
\hline 17 th & Atlantic - North Sea & Netherlands & Ormea & Willem & Still life with fish \\
\hline 17 th & Atlantic - North Sea & Antwerp & van Kessel 1 & Jan & $\begin{array}{l}\text { Nature morte de poissons } \\
\text { au bord d'un rivage }\end{array}$ \\
\hline 17 th & Atlantic - North Sea & Antwerp & van Kessel 1 & Jan & The Day's Catch \\
\hline 17 th & Atlantic - North Sea & Netherlands & Ormea & Willem & $\begin{array}{l}\text { Fish Still Life With } \\
\text { Stormy Seas }\end{array}$ \\
\hline 17 th & Atlantic - North Sea & Netherlands & Martensz & Hendrick & Marché aux poissons \\
\hline 17 th & Atlantic - North Sea & Netherlands & Nieulandt & Jacob van & Poissonniers \\
\hline 17 th & Atlantic - North Sea & Netherlands & Beyeren & Abraham Van & Nature morte à la carpe \\
\hline 17 th & Atlantic - North Sea & Netherlands & Beyeren & Abraham Van & Nature morte aux poissons \\
\hline 17 th & Atlantic - North Sea & Netherlands & Wijtvelt & JB & $\begin{array}{l}\text { Nature morte de poissons } \\
\text { sur une plage }\end{array}$ \\
\hline 17 th & Atlantic - North Sea & Netherlands & Beyeren & Abraham van & Still life with fishes \\
\hline 17 th & Atlantic - North Sea & Netherlands & Gillig & Jacob & Poissons sur la plage \\
\hline 17 th & Atlantic - North Sea & Antwerp & Duynen & Isaac van & Nature morte de poissons \\
\hline 17 th & Atlantic - North Sea & Antwerp & Kessel & Jan I van & Les quatre éléments \\
\hline 18th & Atlantic - North Sea & Paris & Chardin & Jean Siméon & La raie \\
\hline 18th & Atlantic - North Sea & France & Oudry & Jean-Baptiste & Canards et poissons \\
\hline 18 th & Atlantic - North Sea & France & Oudry & Jean-Baptiste & Poissons et oiseaux de mer \\
\hline 18th & Atlantic - North Sea & Netherlands & WB & & Nature morte aux poissons \\
\hline 18th & Atlantic - North Sea & Britain & Blake & Benjamin & Still life with fish \\
\hline 18th & Atlantic - North Sea & Britain & Haughton 1 & Moses & Fish \\
\hline 18th & Atlantic - North Sea & Paris & Jouvenet & Jean-Baptiste & La pêche miraculeuse \\
\hline 18 th & Atlantic - North Sea & France & Angelis & Peter & The fishmonger \\
\hline 18th & Atlantic - North Sea & France & Angelis & Peter & At the marketplace \\
\hline 18th & Atlantic - North Sea & Paris & Desportes & Alexandre-François & Breakfast piece with oysters \\
\hline 18 th & Atlantic - North Sea & France & Oudry & Jean-Baptiste & $\begin{array}{l}\text { Poissons oiseaux de mer } \\
\text { et perroquets }\end{array}$ \\
\hline
\end{tabular}




\section{Appendix 2: Identified taxa}

$\mathrm{CON}=$ Continental, $\mathrm{AMP}=$ Migratory and Pelagic Amphihaline, SEA-D $=$ Sea-Demersal, SEA-P= Sea-Pelagic, SEA-B= Sea-Benthic, SEA $=$ Sea. ANS = Atlantic Ocean and North Sea, EUR= European seas and oceans, INT= Inland waters, MED = Mediterranean Sea. GillNet: Gill nets, BTrawl: Bottom trawling.

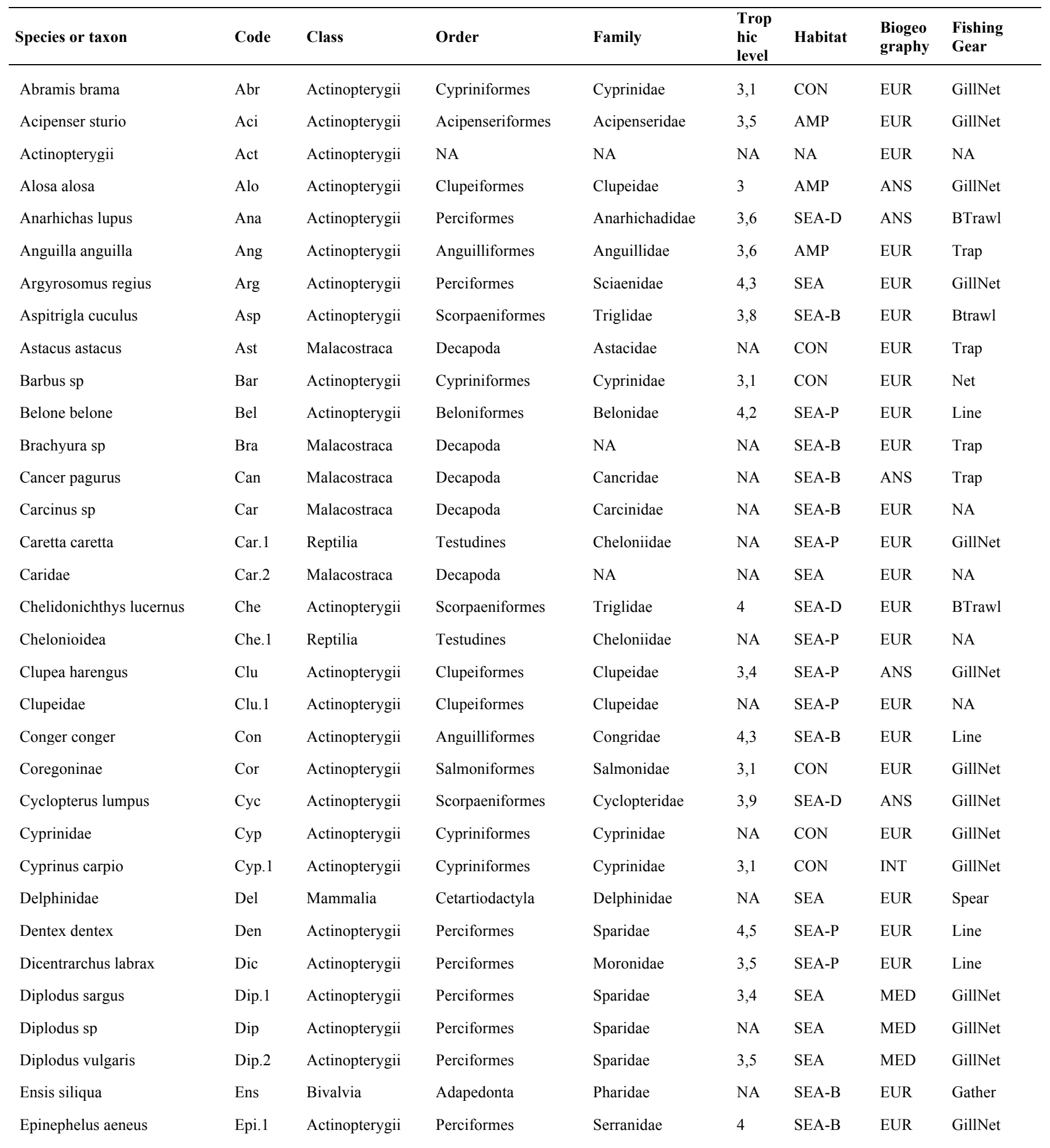




\begin{tabular}{|c|c|c|c|c|c|c|c|c|}
\hline Epinephelus sp & Epi & Actinopterygii & Perciformes & Serranidae & NA & SEA-B & EUR & GillNet \\
\hline Esox lucius & Eso & Actinopterygii & Esociformes & Esocidae & 4,1 & $\mathrm{CON}$ & EUR & GillNet \\
\hline Eutrigla gurnardus & Eut & Actinopterygii & Scorpaeniformes & Triglidae & 3,9 & SEA-D & EUR & BTrawl \\
\hline Gadidae & Gad & Actinopterygii & Gadiformes & Gadidae & NA & SEA-D & EUR & Line \\
\hline Gadus morhua & Gad.1 & Actinopterygii & Gadiformes & Gadidae & 4,1 & SEA-D & ANS & Line \\
\hline Gobio gobio & Gob & Actinopterygii & Cypriniformes & Cyprinidae & 3,1 & $\mathrm{CON}$ & EUR & GillNet \\
\hline Gymnocephalus cernua & Gym & Actinopterygii & Perciformes & Percidae & 3,3 & $\mathrm{CON}$ & EUR & GillNet \\
\hline Haliotis sp & Hal & Gastropoda & Vetigastropoda & Haliotidae & NA & SEA-B & EUR & Gather \\
\hline Hippocampus guttulatus & Hip & Actinopterygii & Syngnathiformes & Syngnathidae & 3,5 & SEA-B & EUR & GillNet \\
\hline Hippoglossus hippoglossus & Hip.1 & Actinopterygii & Pleuronectiformes & Pleuronectidae & 4 & SEA-B & ANS & Line \\
\hline Homarus gammarus & Hom & Malacostraca & Decapoda & Nephropidae & NA & SEA-B & ANS & Trap \\
\hline Labrus sp & $\mathrm{Lab}$ & Actinopterygii & Perciformes & Labridae & NA & SEA & EUR & GillNet \\
\hline Lichia amia & Lic & Actinopterygii & Perciformes & Carangidae & 4,5 & SEA-P & MED & Line \\
\hline Lithognathus mormyrus & Lit & Actinopterygii & Perciformes & Sparidae & 3,4 & SEA-B & MED & GillNet \\
\hline Liza sp & Liz & Actinopterygii & Perciformes & Mugilidae & 2,3 & AMP & ANS & GillNet \\
\hline Loligo sp & Lol & Cephalopoda & Myopsida & Loliginidae & NA & SEA-P & ANS & Line \\
\hline Lotidae & Lot & Actinopterygii & Gadiformes & Lotidae & NA & SEA-B & EUR & BTrawl \\
\hline Lutra lutra & Lut & Mammalia & Carnivora & Mustelidae & NA & $\mathrm{CON}$ & EUR & Spear \\
\hline Maja brachydactyla & Maj.1 & Malacostraca & Decapoda & Majidae & NA & SEA-B & ANS & Trap \\
\hline Maja sp & Maj & Malacostraca & Decapoda & Majidae & NA & SEA-B & EUR & Trap \\
\hline Maja squinado & Maj.2 & Malacostraca & Decapoda & Majidae & NA & SEA-B & MED & Trap \\
\hline Melanogrammus aeglefinus & Mel & Actinopterygii & Gadiformes & Gadidae & 4 & SEA-D & ANS & Btrawl \\
\hline Merluccius merluccius & Mer & Actinopterygii & Gadiformes & Merlucciidae & 4,4 & SEA-D & EUR & Btrawl \\
\hline Mola mola & Mol & Actinopterygii & Tetraodontiformes & Molidae & 3,3 & SEA-P & EUR & GillNet \\
\hline Monachus monachus & Mon & Mammalia & Carnivora & Phocidae & NA & SEA & MED & Spear \\
\hline Mugilidae & Mug & Actinopterygii & Perciformes & Mugilidae & 2,6 & AMP-P & EUR & GillNet \\
\hline Mullus sp & Mul & Actinopterygii & Perciformes & Mullidae & 3,1 & SEA-B & EUR & BTrawl \\
\hline Mullus surmuletus & Mul.1 & Actinopterygii & Perciformes & Mullidae & 3,5 & SEA-B & EUR & GillNet \\
\hline Muraena helena & Mur & Actinopterygii & Anguilliformes & Muraenidae & 4,2 & SEA-B & EUR & Trap \\
\hline Myoxocephalus scorpius & Myo & Actinopterygii & Scorpaeniformes & Cottidae & 3,9 & SEA-D & ANS & BTrawl \\
\hline Mytilus sp & Myt & Bivalvia & Mytilida & Mytilidae & NA & SEA-B & EUR & Gather \\
\hline Octopus vulgaris & Oct & Cephalopoda & Octopoda & Octopodidae & NA & SEA-B & EUR & Trap \\
\hline Odobenus rosmarus & Odo & Mammalia & Carnivora & Odobenidae & NA & SEA & ANS & Spear \\
\hline Ostrea edulis & Ost & Bivalvia & Ostreida & Ostreidae & NA & SEA-B & EUR & Gather \\
\hline Pagellus sp & Pag & Actinopterygii & Perciformes & Sparidae & 3,5 & SEA & EUR & GillNet \\
\hline Pagrus pagrus & Pagp & Actinopterygii & Perciformes & Sparidae & 3,9 & SEA & EUR & GillNet \\
\hline Pagrus sp & Pagr & Actinopterygii & Perciformes & Sparidae & 3,9 & SEA & EUR & GillNet \\
\hline Palaemon sp & Pal & Malacostraca & Decapoda & Palaemonidae & NA & SEA & EUR & Gather \\
\hline Palinurus elephas & Pali & Malacostraca & Decapoda & Palinuridae & NA & SEA-B & EUR & Trap \\
\hline Paracentrotus lividus & Par & Echinoidea & Camarodonta & Parechinidae & NA & SEA-B & EUR & Gather \\
\hline
\end{tabular}




\begin{tabular}{|c|c|c|c|c|c|c|c|c|}
\hline Patella ferruginea & Pat & Gastropoda & Archaeogastropoda & Patellidae & NA & SEA-B & MED & Gather \\
\hline Perca fluviatilis & Per & Actinopterygii & Perciformes & Percidae & 4,4 & $\mathrm{CON}$ & EUR & GillNet \\
\hline Petromyzon marinus & Pet & Petromyzonti & Petromyzontiformes & Petromyzontidae & 4,4 & AMP & EUR & Trap \\
\hline Phoca vitulina & Phov & Mammalia & Carnivora & Phocidae & NA & SEA & ANS & Spear \\
\hline Phocidae & Pho & Mammalia & Carnivora & Phocidae & NA & SEA & EUR & Spear \\
\hline Phocoena phocoena & Phop & Mammalia & Cetartiodactyla & Phocoenidae & NA & SEA & EUR & Spear \\
\hline Platichthys flesus & Pla & Actinopterygii & Pleuronectiformes & Pleuronectidae & 3,3 & SEA-D & EUR & GillNet \\
\hline Plectorhincus mediterraneus & Ple & Actinopterygii & Perciformes & Haemulidae & 3,5 & SEA & MED & Line \\
\hline Pleuronectes platessa & Plep & Actinopterygii & Pleuronectiformes & Pleuronectidae & 3,2 & SEA-D & ANS & GillNet \\
\hline Pleuronectidae & Ple.1 & Actinopterygii & Pleuronectiformes & Pleuronectidae & NA & SEA-D & EUR & GillNet \\
\hline Pollachius sp & Pol & Actinopterygii & Gadiformes & Gadidae & NA & SEA-D & ANS & BTrawl \\
\hline Pollachius virens & Polv & Actinopterygii & Gadiformes & Gadidae & 4,3 & SEA-D & ANS & BTrawl \\
\hline Raja clavata & Rajc & Elasmobranchii & Rajiformes & Rajidae & 3,8 & SEA-D & EUR & Line \\
\hline Rajidae & Raj & Elasmobranchii & Rajiformes & Rajidae & NA & SEA-D & EUR & Line \\
\hline Rutilus rutilus & Rut & Actinopterygii & Cypriniformes & Cyprinidae & 3 & $\mathrm{CON}$ & EUR & GillNet \\
\hline Salmo salar & Sals & Actinopterygii & Salmoniformes & Salmonidae & 4,5 & AMP & ANS & GillNet \\
\hline Salmo sp & Sal & Actinopterygii & Salmoniformes & Salmonidae & NA & $\mathrm{CON}$ & EUR & GillNet \\
\hline Salmo trutta & Salt & Actinopterygii & Salmoniformes & Salmonidae & 3,4 & $\mathrm{CON}$ & EUR & Line \\
\hline Sardina pilchardus & Sarp & Actinopterygii & Clupeiformes & Clupeidae & 3,1 & SEA-P & EUR & GillNet \\
\hline Sarpa salpa & Sars & Actinopterygii & Perciformes & Sparidae & 2 & SEA-BP & MED & GillNet \\
\hline Scardinius erythrophthalmus & Sca & Actinopterygii & Cypriniformes & Cyprinidae & 2,9 & $\mathrm{CON}$ & EUR & GillNet \\
\hline Scomber colias & Scoc & Actinopterygii & Perciformes & Scombridae & 3,9 & SEA-P & MED & GillNet \\
\hline Scomber scombrus & Scos & Actinopterygii & Perciformes & Scombridae & 3,6 & SEA-P & EUR & GillNet \\
\hline Scophtalmidae & Scop & Actinopterygii & Pleuronectiformes & Scophthalmidae & NA & SEA-D & EUR & GillNet \\
\hline Scorpaena porcus & Scorp & Actinopterygii & Scorpaeniformes & Scorpaenidae & 3,9 & SEA-B & EUR & GillNet \\
\hline Scorpaena scorfa & Scors & Actinopterygii & Scorpaeniformes & Scorpaenidae & 4,3 & SEA-B & EUR & GillNet \\
\hline Scorpaena sp & Scor & Actinopterygii & Scorpaeniformes & Scorpaenidae & NA & SEA-B & EUR & GillNet \\
\hline Scorpaenidae & Sco & Actinopterygii & Scorpaeniformes & Scorpaenidae & NA & SEA-B & EUR & GillNet \\
\hline Scyliorhinus sp & Scy & Elasmobranchii & Carcharhiniformes & Scyliorhinidae & NA & SEA-B & EUR & GillNet \\
\hline Scyliorhinus stellaris & Scys & Elasmobranchii & Carcharhiniformes & Scyliorhinidae & 4 & SEA-B & EUR & GillNet \\
\hline Scyllarides latus & Scyl & Malacostraca & Decapoda & Scyllaridae & NA & SEA-B & MED & Trap \\
\hline Sebastes sp & Seb & Actinopterygii & Scorpaeniformes & Sebastidae & NA & SEA-D & EUR & BTrawl \\
\hline Sepia officinalis & Sep & Cephalopoda & Sepiida & Sepiidae & NA & SEA-B & EUR & Trap \\
\hline Serranus sp & Ser & Actinopterygii & Perciformes & Serranidae & NA & SEA & EUR & GillNet \\
\hline Siluridae & Sil & Actinopterygii & Siluriformes & Siluridae & NA & $\mathrm{CON}$ & EUR & GillNet \\
\hline Solea solea & Sol & Actinopterygii & Pleuronectiformes & Soleidae & 3,2 & SEA-B & EUR & GillNet \\
\hline Sparidae & Spa & Actinopterygii & Perciformes & Sparidae & NA & SEA & EUR & GillNet \\
\hline Sparus aurata & Spaa & Actinopterygii & Perciformes & Sparidae & 3,7 & SEA & EUR & GillNet \\
\hline Spondyliosoma cantharus & Spo & Actinopterygii & Perciformes & Sparidae & 3,3 & SEA & EUR & GillNet \\
\hline Squilla mantis & Squ & Malacostraca & Stomatopoda & Squillidae & NA & SEA-B & MED & Trap \\
\hline
\end{tabular}




\begin{tabular}{|c|c|c|c|c|c|c|c|c|}
\hline Symphodus sp & Sym & Actinopterygii & Perciformes & Labridae & NA & SEA & EUR & GillNet \\
\hline Thonidae & Tho & Actinopterygii & Perciformes & Scombridae & NA & SEA-P & EUR & GillNet \\
\hline Thunnus thynnus & Thu & Actinopterygii & Perciformes & Scombridae & 4,5 & SEA-P & EUR & GillNet \\
\hline Tinca tinca & Tin & Actinopterygii & Cypriniformes & Cyprinidae & 3,7 & $\mathrm{CON}$ & EUR & GillNet \\
\hline Trachinidae & Tra & Actinopterygii & Perciformes & Trachinidae & NA & SEA-B & EUR & GillNet \\
\hline Trachinotus ovatus & Trao & Actinopterygii & Perciformes & Carangidae & 3,7 & SEA-P & EUR & GillNet \\
\hline Trachinus radiatus & Trar & Actinopterygii & Perciformes & Trachinidae & 4,2 & SEA-B & EUR & GillNet \\
\hline Trachurus sp & Trac & Actinopterygii & Perciformes & Carangidae & 3,7 & SEA-P & EUR & GillNet \\
\hline Trigla lyra & Tril & Actinopterygii & Scorpaeniformes & Triglidae & 3,7 & SEA-D & EUR & BTrawl \\
\hline Triglidae & Tri & Actinopterygii & Scorpaeniformes & Triglidae & NA & SEA-D & EUR & BTrawl \\
\hline Trisopterus luscus & Trisl & Actinopterygii & Gadiformes & Gadidae & 3,7 & SEA & ANS & GillNet \\
\hline Trisopterus minutus & Trism & Actinopterygii & Gadiformes & Gadidae & 3,7 & SEA & ANS & GillNet \\
\hline Veneridae & Ven & Bivalvia & Venerida & Veneridae & NA & SEA-B & EUR & Gather \\
\hline Zeus faber & Zeu & Actinopterygii & Zeiformes & Zeidae & 4,5 & SEA-D & EUR & BTraw \\
\hline
\end{tabular}


Appendix 3: Example illustrations

a)

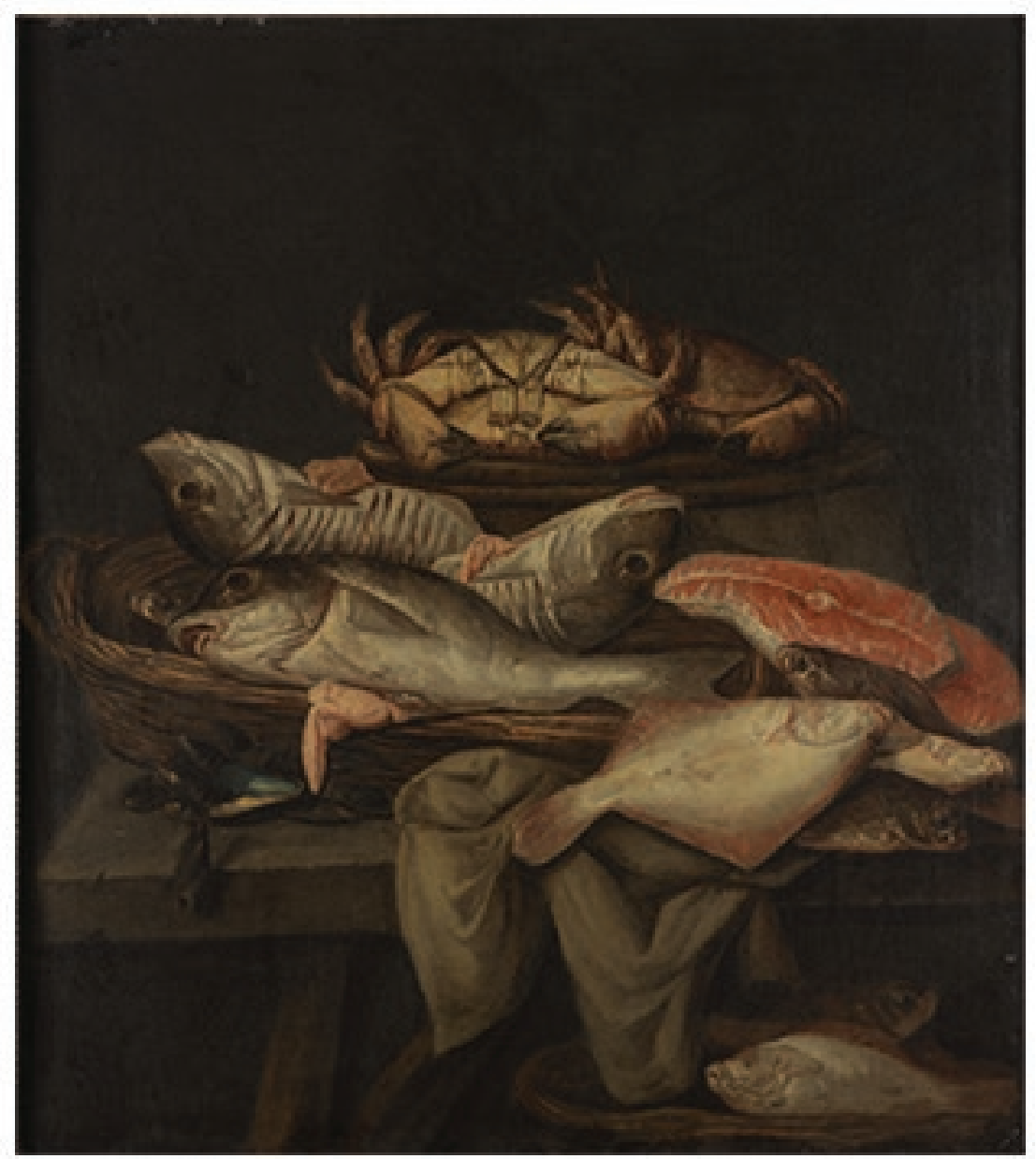

Abraham Hendricksz van Beyeren, Still Life of Fish, 1655, Netherlands RISD Musuem, Providence, USA.

b)

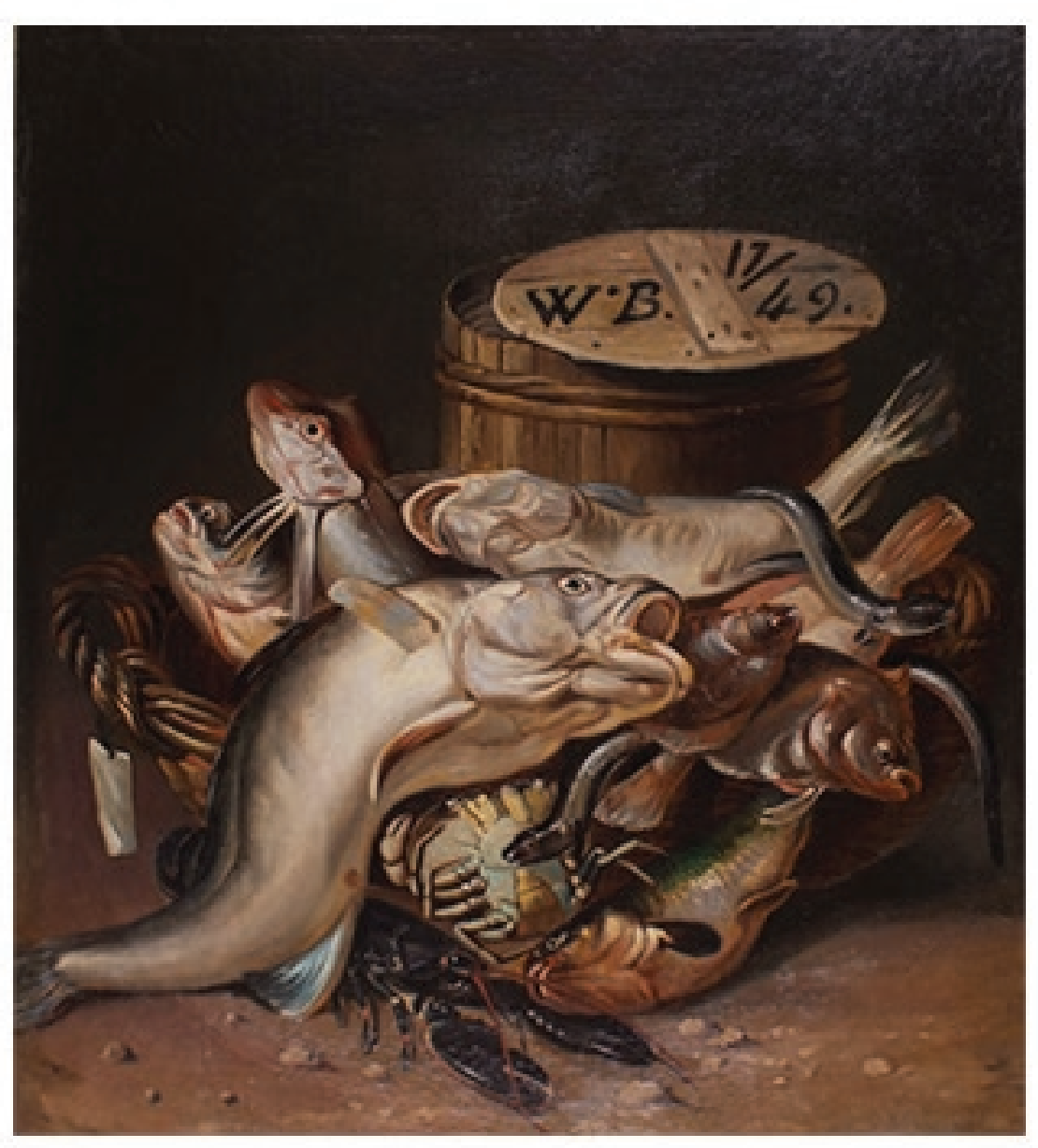

W.B., Nature morte aux poissons

Musée maritime de l'île Tatihou, Conseil départemental de la Manche. This work was destroyed during the fire in the museum reserves on July 18, 2017. 